\title{
The nature and origin of the Barrovian metamorphism, Scotland: diffusion length scales in garnet and inferred thermal time scales
}

\author{
DANIEL R. VIETE*, JÖRG HERMANN, GORDON S. LISTER \& IONA R. STENHOUSE \\ Research School of Earth Sciences, Australian National University, Canberra, ACT 2601, Australia \\ *Corresponding author (e-mail: daniel.viete@gmail.com)
}

\begin{abstract}
In this paper we examine the length scales of major element diffusion in garnet during the Barrovian metamorphism. The role of diffusion in the flattening of $\mathrm{Mn}$ zoning profiles in garnet with increasing metamorphic grade across the Barrovian metamorphic series is ambiguous. However, the loss of distinct Mn-defined secondary compositional zoning in Barrovian garnets with increasing metamorphic grade and preservation of geochemical textures around $\mathrm{Mn}$-free inclusions within high-grade Barrovian garnets provide robust evidence for $c .1000 \mu \mathrm{m}$ Mn diffusion in sillimanite-zone garnets during the Barrovian regional metamorphism. Sillimanite-grade garnets from the Barrovian metamorphic series also preserve c. $100 \mu \mathrm{m} \mathrm{Mn}$ diffusion textures between sillimanite-grade rim domains and lower-grade cores. Bimodality in diffusion length scales requires bimodality in thermal time scales. Length scales of chemical diffusion are considered within the context of recent duration estimates for the Barrovian metamorphism of a few million years. We conclude that heat associated with the Barrovian regional metamorphism accumulated following numerous, short time-scale heating events responsible for the smaller-scale diffusion textures. This self-similar thermal regime was likely accommodated by the operation of shear zones in the highest-grade regions of the Barrovian metamorphic series, which concentrated small-scale episodic heat sources such as sheeted magmas, fluids and/ or mechanical work.
\end{abstract}

Supplementary material: A table of quantitative electron microprobe analyses, an example of the calibration curve used to produce quantitative electron microprobe maps from count maps, and Y maps are available at http://www.geolsoc.org.uk/SUP18415.

The degree of completion of temperature-dependent processes, as recorded in rocks or minerals, can provide information on the duration of heating events. Lasaga (1983) first introduced the study of 'geospeedometry' with reference to the use of chemical diffusion textures to study the duration of thermal events. Geospeedometry is concerned with either inter-diffusion of elements between mineral pairs (multicrystalline geospeedometry) or self-diffusion of ionic species within a single mineral (monocrystalline geospeedometry).

In 1977, three studies reported on the loss of compositional zoning in garnets with increasing metamorphic grade within an amphibolite-grade metamorphic sequence, a phenomenon each researcher attributed to homogenization of garnet chemistry by chemical diffusion at significant temperatures (Anderson \& Olimpio 1977; Woodsworth 1977; Yardley 1977). Recently, Ague \& Baxter (2007) described sub-grain-scale (c. $100 \mu \mathrm{m})$, diffusion-related features in sillimanite-grade garnets from the Barrovian metamorphic series, Scotland, which they considered evidence of major element diffusion during regional metamorphic heating. They reasoned that diffusion of major elements in garnet during the Barrovian regional metamorphism was limited to the sub-grain $(c .100 \mu \mathrm{m})$ scale and that loss of compositional zoning in Barrovian garnets, with increasing metamorphic grade, was caused by variation in garnet growth systematics across metamorphic grade (see Atherton 1968).

In this paper, we report on the results of a systematic investigation into the nature of major element and rare earth element (REE) zoning preserved in garnets from the Barrovian metamorphic series and the manner by which geochemical zoning of garnet varies with increasing metamorphic grade. We have sought to identify whether homogenization of Barrovian garnet compositions with increasing metamorphic grade resulted from growth processes or syn- to post-growth diffusion processes. In particular we address two questions: whether Barrovian garnets display evidence of diffusion of major elements over length scales sufficiently large to account for up-metamorphicgrade homogenization of garnet compositions, and whether Barrovian garnets record evidence of diffusion on a variety of length scales. The results of this study have implications for the durations of metamorphic heating that gave rise to the Barrovian thermal event during the Grampian orogenic episode in Scotland, and for the diffusivity of major elements in garnet at amphibolite-facies temperatures.

\section{Geological background}

The Barrovian metamorphic series (Barrow 1893, 1912) occurs in the SE of the Grampian Terrane, Scotland (Fig. 1). It developed at c. 470 Ma (Oliver et al. 2000; Baxter et al. 2002; Breeding et al. 2004), during the Grampian orogeny of Lambert \& McKerrow (1976). Recent work has shown that the Barrovian metamorphic series developed as the result of a thermal event of relatively short duration, of the order of a few million years (Dewey \& Mange 1999; Reverdatto \& Polyansky 2004; Viete et al. 2010b) or less (Ague \& Baxter 2007).

This well-studied metamorphic sequence provides us with a natural laboratory to study length scales of diffusion-related geochemical textures preserved in garnet, and thereby assess the nature of heating during metamorphism of the middle crust in a convergent margin setting. The study discussed in this paper 


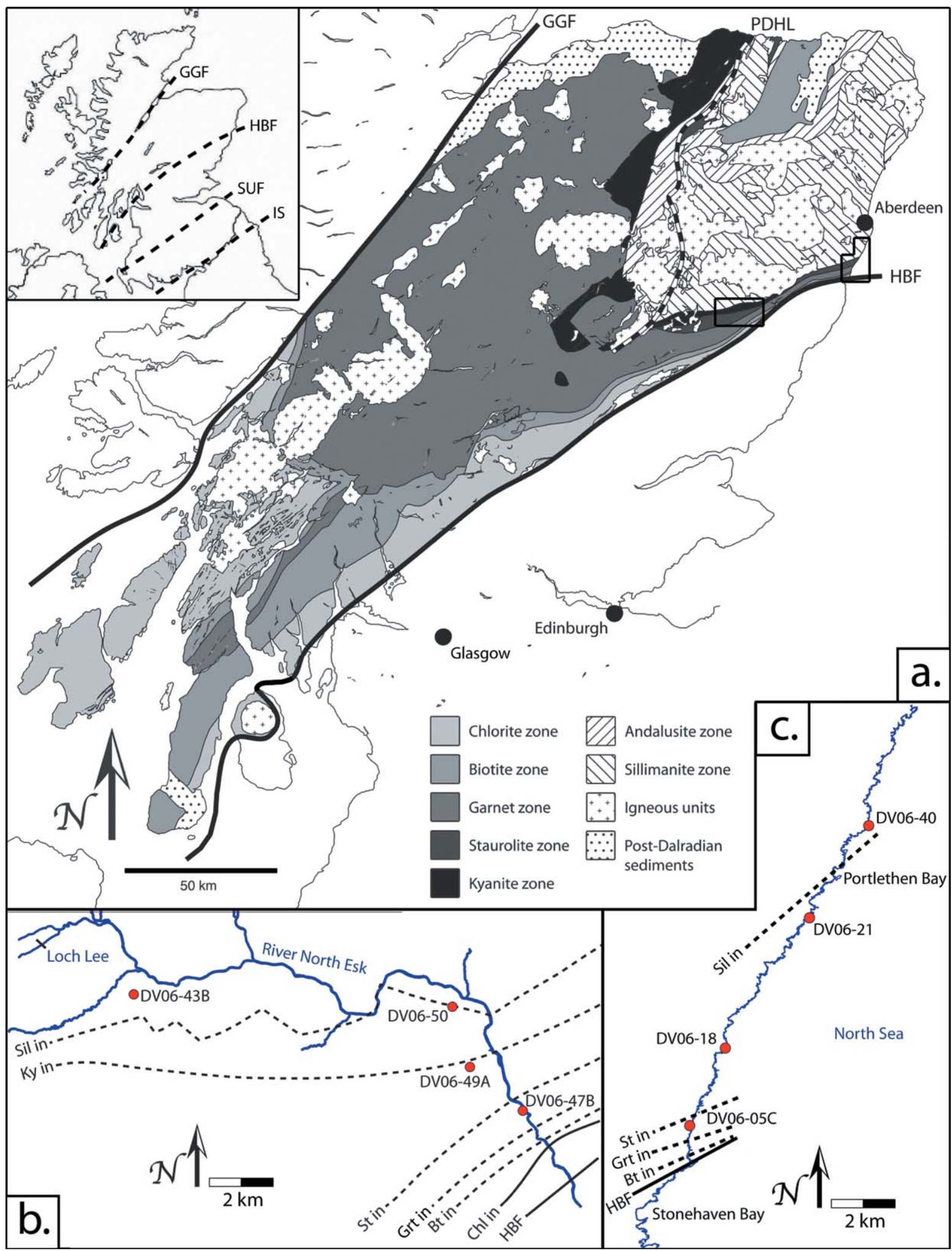

Fig. 1. Map of the Grampian Terrane, Scotland, showing (a) the distribution of metamorphic mineral isograds, magmatic bodies and post-Grampian sediments, (b) localities for garnet samples from the Glen Esk transect (enlargement of rectangle in (a)) and (c) localities for garnet samples from the Stonehaven transect (enlargement of polygon in (a)). Inset at top left of (a) provides a regional map. GGF, Great Glen Fault; HBF, Highland Boundary Fault; IS, Iapetus Suture; PDHL, Portsoy-Duchray Hill Lineament; SUF, Southern Uplands Fault. Compiled after Barrow (1912), Elles \& Tilley (1930), Hudson (1980), Fettes et al. (1986) and Harte (1987). Mineral abbreviations follow the recommendations of Kretz (1983). 
utilizes two transects through the Barrovian metamorphic series: the Glen Esk transect, which follows the river North Esk (Fig. 1b), and the Stonehaven transect on the Scottish east coast (Fig. 1c). Across both these transects, metamorphic grade increases from chlorite to sillimanite grade to the NW, away from the terrane-bounding Highland Boundary Fault (Fig. 1). Results presented here concern garnets sampled from the various garnetbearing mineral zones of the Barrovian metamorphic series. These are, in the direction of increasing metamorphic grade, the garnet, staurolite, kyanite and sillimanite zones.

A number of investigations have been carried out on compositional zoning in garnets from the Barrovian metamorphic series of Scotland. Atherton (1968), in a study on chlorite, biotite and garnet composition in medium-grade Dalradian pelites, recognized in garnets a strong compositional zoning whose origin he suggested lay in changes in the composition of garnet with increasing temperature during progressive mineral growth. Dempster (1985) published compositional zoning profiles for garnets sampled from the garnet zone to the sillimanite zone, across a transect through the Barrovian metamorphic series. The work of Dempster (1985) shows that there exists a clear correlation between metamorphic grade and the nature of compositional zoning in Dalradian garnets, with flattening of zoning profiles accompanying an increase in metamorphic grade. Ayres \& Vance (1997) revisited the data of Atherton (1968), comparing 'diffusively modified' Mn growth profiles from Scotland with those obtained for Himalayan garnets to conclude, on qualitative grounds, that the Barrovian metamorphism of Scotland (in total) outlasted Himalayan (Barrovian-type) metamorphism by a factor of 10-20. Ague \& Baxter (2007) identified small-scale $(c .100 \mu \mathrm{m})$ diffusion features in garnets from the highest-grade units of the Barrovian metamorphic series. They proposed that diffusion length scales for major cations in Barrovian garnets are limited to $c .100 \mu \mathrm{m}$ and that variation in garnet compositional zoning with increasing metamorphic grade did not develop as the result of grain-scale diffusion during the regional metamorphism, but reflects different garnet growth conditions across the Barrovian metamorphic series. They, like Atherton (1968) before them, contended that the presence or absence of minerals capable of sequestering $\mathrm{Mn}$ (e.g. oxides and epidote-group minerals) during garnet growth could account for variation in Mn zoning across metamorphic grade. The origin of changes in compositional zoning of Barrovian garnets with increasing metamorphic grade (diffusion v. growth) remains an issue of contention.

\section{Methods}

To study major and trace element zoning preserved in Barrovian garnets, we employed a combined analytical approach. We first used high-resolution major element mapping carried out using an electron microprobe to obtain 2D distribution patterns for the concentration of the major elements in garnet, providing a good overview of the context of geochemical features. From the maps produced, we chose representative profiles to show the main features of the major element zoning. Although these profiles are of high resolution, they are of relatively low sensitivity, because of the relatively short counting time employed for the mapping. Rather than reproducing the profiles with fully quantified electron microprobe spot profiles, we chose to obtain highresolution, high-sensitivity quantitative composition profiles for the garnets by laser ablation inductively coupled plasma mass spectrometry (LA-ICP-MS). This approach has an advantage over the electron microprobe in that it is capable of simulta- neously collecting both major and trace element data. Thus, data collected from quantitative traverses of the Barrovian garnets using LA-ICP-MS could be used to directly compare the major and trace element zoning characteristics of the garnets. Using this combined analytical approach we produced a comprehensive dataset of major and trace element zoning for garnets from across the Barrovian metamorphic series, which provided us with a basis to assess growth and diffusion features.

\section{Garnet major element (and Y) geochemistry}

Major element (and Y) geochemical characterization of garnets was carried out on the Cameca SX100 electron microprobe at the Research School of Earth Sciences (RSES), The Australian National University (ANU). Polished thin sections were produced from garnetiferous pelites and the largest garnets (those most likely to represent the middle section of a crystal) were chosen for analysis. All analyses were performed by wavelengthdispersive spectrometry (WDS). For each garnet analysed, count values were obtained for $\mathrm{Ca}, \mathrm{Fe}, \mathrm{Mg}$ and $\mathrm{Mn}$ at points spaced between 4 and $6 \mu \mathrm{m}$, which formed a rectangular grid covering the crystal. Count analyses were made using a $15 \mathrm{keV}$ acceleration voltage, $40 \mathrm{nA}$ beam current and $0.025 \mathrm{~s}$ dwell time. For some grains, count analyses made at between 6 and $10 \mu \mathrm{m}$ spacings were used to produce $\mathrm{Y}$ count maps. Yttrium count analyses employed a $15 \mathrm{keV}$ acceleration voltage, $500 \mathrm{nA}$ beam current and $0.5 \mathrm{~s}$ dwell time.

Count values were converted to $\mathrm{wt} \%$ or ppm using a linear best-fit solution that mapped WDS counts to values of $\mathrm{wt} \%$ (or $\mathrm{ppm}$ ) for each sample. Five to 10 quantitative spot analyses made at points with known $\mathrm{Ca}, \mathrm{Fe}, \mathrm{Mg}, \mathrm{Mn}$ (and $\mathrm{Y}$ ) count values provided the dataset to which the linear function was fitted for each garnet. Background count values were found by extrapolation of the linear function to the count value at $0 \mathrm{wt} \%$ element abundance. An acceleration volume of $15 \mathrm{keV}$, beam current of $40 \mathrm{nA}$, beam diameter of $5 \mu \mathrm{m}$ and collection time of $3 \mathrm{~s}$ were used for all quantitative analyses. All quantitative spot analyses used natural and synthetic standards of known composition. Calibration of count maps to absolute values of composition was carried out using the ImageJ computer program. Representative compositional profiles were extracted from the absolute-value maps using the ImageJ software. To remove excessive noise in compositional profiles from the electron microprobe maps, values defining the compositional profiles were calculated from sevenpoint sliding averages.

\section{Garnet REE geochemistry}

Selected garnets from the polished sections produced for major element work were analysed for trace element and REE geochemistry by LA-ICP-MS. Analyses were carried out using an Agilent 7500 series quadropole ICP-MS system, equipped with an ArF Excimer laser system (193 nm wavelength) and custom-built sample cell and transport system (details have been given by Eggins et al. 1998), housed at the RSES, ANU. The laser, with a pulse rate of $5 \mathrm{~Hz}$ and laser irradiance of about $70 \mathrm{~J} \mathrm{~m}^{-2}$, was focused to produce an ablation pit $54 \mu \mathrm{m}$ in diameter. During each analysis, the sample was displaced with a velocity of $650 \mu \mathrm{m} \mathrm{min}^{-1}$, to produce a $54 \mu \mathrm{m}$ wide and c. $3 \mu \mathrm{m}$ deep ablation trench that provided the material for analysis. Ablation was performed into a $\mathrm{He}-\mathrm{Ar}$ carrier gas above the sampling site for injection into a signal smoothing manifold and then plasma. A peak-hopping approach for data acquisition was employed, whereby intensity data for single elements were 
collected during periodic (period of $c .0 .6 \mathrm{~s}$ ) mass spectrometer sweeps. For each garnet traverse, analysis was carried out for $30-35 \mathrm{~s}$ prior to collection of analyte to characterize the gas background signal. The NIST 610 synthetic glass (Pearce et al. 1997) was used as a standard material. $\mathrm{SiO}_{2}$ concentration, as determined from quantitative electron microprobe analyses, was used as an internal standard. Data reduction used a macro-based Excel spreadsheet developed at the RSES, ANU. To remove excessive noise in the LA-ICP-MS compositional transects, values defining the transects were calculated from seven-point sliding averages.

\section{Major element zoning in Barrovian garnets}

Grain-scale major element ( $\mathrm{Ca}, \mathrm{Fe}, \mathrm{Mg}, \mathrm{Mn})$ zoning was investigated for eight samples gathered from the Glen Esk (four samples: Fig. 1b) and Stonehaven (four samples: Fig. 1c) transects through the Barrovian metamorphic series (Fig. 1a), with particular reference to the manner by which compositional zoning in garnets changes with increasing metamorphic grade. Numerous grains were mapped for each sample but, for the purpose of economy, only representative analyses are presented in the results. Table 1 summarizes relevant details of the major element zoning of the garnets whose geochemistry is discussed below.

\section{Results}

Garnets from the Barrovian metamorphic series, in all but some high-grade (sillimanite-zone) cases, display compositional zoning in the major divalent cations that reside in garnet $(\mathrm{Ca}, \mathrm{Fe}, \mathrm{Mg}$, $\mathrm{Mn}$ ). From core to rim, the grossular (Ca garnet) and spessartine (Mn garnet) content of zoned Barrovian garnets decrease, whereas almandine (Fe garnet) and pyrope ( $\mathrm{Mg}$ garnet) contents increase. Some garnets from higher-grade (sillimanite-grade) units display resorption textures (see Kohn \& Spear 2000) at their edge, which are defined by a downward inflection in grossular, almandine and pyrope profiles and a sharp upward inflection in spessartine profiles. The first two columns of Figures 2 and 3 display major element maps and profiles, respectively, for representative samples from the staurolite zone of the Stonehaven transect (DV06-18) and from the sillimanite-in isograd on the Glen Esk transect (DV06-50).

The clearest manifestation of growth zoning in Barrovian garnets occurs in the distribution of $\mathrm{Mn}$, an element that is highly compatible in garnet with respect to minerals that coexist with garnet in metapelites. The last two columns of Figures 2 and 3 display $\mathrm{Mn}$ abundance maps and profiles, respectively, for garnets from four samples collected on each of the Glen Esk and Stonehaven transects of Figure 1. The garnets exhibit Mn corerim zoning from the lowest grades. Profiles display a bell-shaped form and can, in the higher metamorphic grades, show an upward inflection in spessartine content at the grain edge. With increasing metamorphic grade, a systematic decrease in maximum $\mathrm{Mn}$ concentrations in garnet cores and core-to-rim differences in $\mathrm{Mn}$ abundance can be observed (Figs 2 and 3). Manganese concentration in grain cores varies from about 6.0$7.5 \mathrm{wt} \%$ in garnets from the garnet zone and lower-grade parts of the staurolite zone to around $3.0-5.0 \mathrm{wt} \%$ for garnets from the higher-grade parts of the staurolite zone and the sillimanite zone (Figs 2 and 3). It should be mentioned that cutting effects have an impact on the zoning displayed by a garnet: an off-centre cut can dampen core-to-rim compositional variations relative to those that a central section would display. This, however, occurs solely because of an apparent change in core concentration, and concentration at the rim edge should be independent of any cutting effect.

Garnets from the sillimanite zone of the Barrovian metamorphic series commonly display textural zoning in the form of sillimanite-grade overgrowths on an inclusion-rich (generally quartz and white mica) core (see Baxter et al. 2002). Manganese maps for such garnets exhibit c. $100 \mu \mathrm{m}$ wide 'fuzzing bands'

Table 1. Summary table giving sample localities, position within the Barrovian metamorphic series, peak metamorphic temperature estimates and details on garnet geochemical features

\begin{tabular}{|c|c|c|c|c|c|c|}
\hline Sample & Transect & GPS & $\begin{array}{l}\text { Metamorphic } \\
\text { zone }\end{array}$ & $\begin{array}{l}\text { Estimated peak } \\
\text { metamorphic conditions* }\end{array}$ & $\begin{array}{l}\text { Y-rich } \\
\text { core? }\end{array}$ & Diffusion features \\
\hline DV06-47B & Glen Esk & NO57877438 & Grt zone & $540^{\circ} \mathrm{C}, 4.4 \mathrm{kbar}$ & Yes & $\begin{array}{l}250 \mu \mathrm{m} \text { irregularities in } \mathrm{Mn} \text { and } \mathrm{Ca} \\
\text { concentration profiles }\end{array}$ \\
\hline DV06-49A & Glen Esk & NO56207575 & St zone & $620^{\circ} \mathrm{C}, 5.7 \mathrm{kbar}$ & No & $\begin{array}{l}\text { Low-Mn concentration shadow rim- } \\
\text { side of Mn-free inclusion cluster }\end{array}$ \\
\hline DV06-50 & Glen Esk & NO55657765 & Sil zone & $640^{\circ} \mathrm{C}, 5.9 \mathrm{kbar}$ & No & $\begin{array}{l}100 \mu \mathrm{m} \text { Mn 'fuzzing' band between } \\
\text { low-grade core domain and higher- } \\
\text { grade rim domain } \\
500 \mu \mathrm{m} \text { irregularities in } \mathrm{Ca} \\
\text { concentration profiles with no } \\
\text { corresponding Mn irregularities in } \\
\text { core }\end{array}$ \\
\hline DV06-43B & Glen Esk & NO45647802 & Sil zone & $670^{\circ} \mathrm{C}, 6.1 \mathrm{kbar}$ & No & $\begin{array}{l}800-1000 \mu \mathrm{m} \text { irregularities in } \mathrm{Ca} \\
\text { concentration profiles with no } \\
\text { corresponding Mn irregularities }\end{array}$ \\
\hline DV06-05C & Stonehaven & NO89248874 & Grt zone & $530^{\circ} \mathrm{C}, 4.2 \mathrm{kbar}$ & No & \\
\hline DV06-18 & Stonehaven & NO90279097 & St zone & $590^{\circ} \mathrm{C}, 5.5 \mathrm{kbar}$ & Yes & $\begin{array}{l}250 \mu \mathrm{m} \text { irregularities in } \mathrm{Mn} \text { and } \mathrm{Ca} \\
\text { concentration profiles; irregularities } \\
\text { more subtle for } \mathrm{Mn} \text { than for } \mathrm{Ca}\end{array}$ \\
\hline DV06-21 & Stonehaven & NO92719474 & St zone & $620^{\circ} \mathrm{C}, 5.7 \mathrm{kbar}$ & No & $\begin{array}{l}\text { Low-Mn concentration shadows } \\
\text { rim-side of large Mn-poor inclusion }\end{array}$ \\
\hline DV06-40 & Stonehaven & NO94439741 & Sil zone & $660^{\circ} \mathrm{C}, 6.0 \mathrm{kbar}$ & Yes & \\
\hline
\end{tabular}

Mineral abbreviations follow the recommendations of Kretz (1983).

* Estimated using preserved peak metamorphic assemblages and MnNCKFMASH pseudosections produced for average Barrovian pelite compositions (Viete 2009). These temperature estimates are in near perfect agreement with those used by Ague \& Baxter (2007) for their work on the Barrovian metamorphic series. 


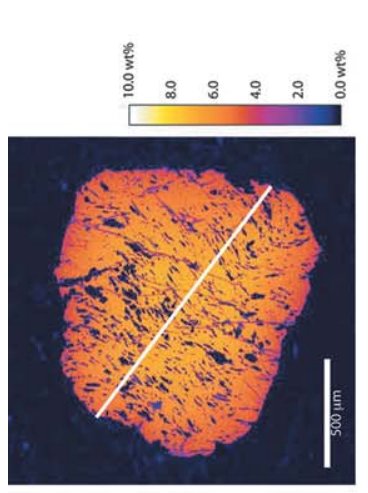

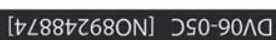

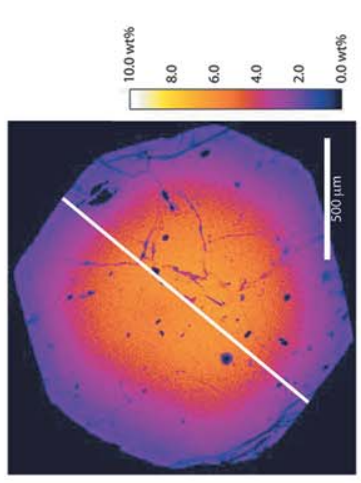

[L606LZ06ON] 8l-90^0

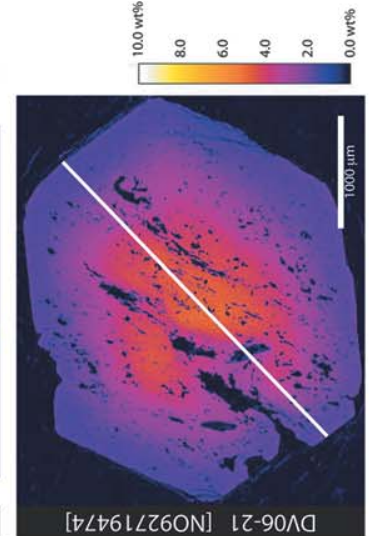

[
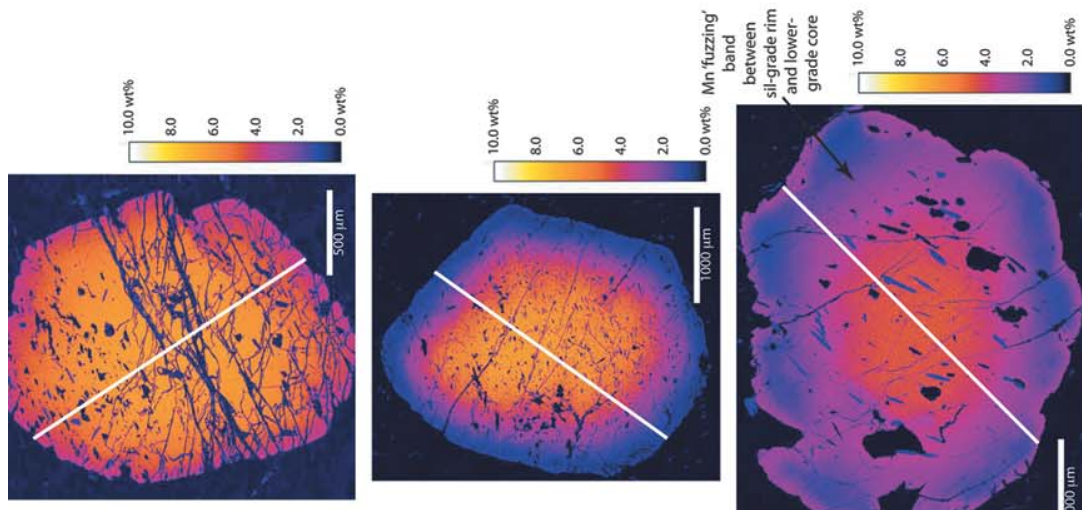

$[8 \varepsilon t \angle L 8 \angle S O N] 8 \angle t-90 \wedge 0$

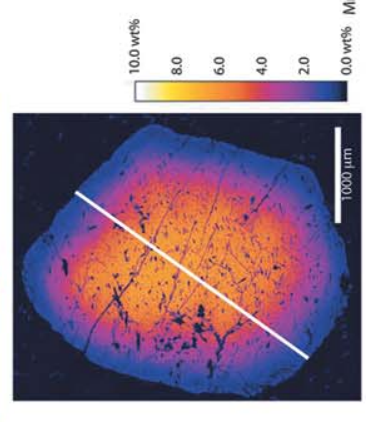

[SLSLOZ9SON] $\forall 6 \mathrm{t}-90 \wedge a$

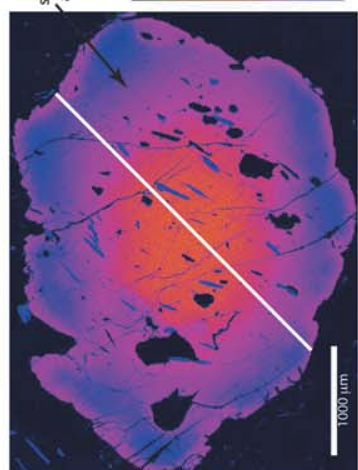

[S9LLS9SSON] OS-90^A

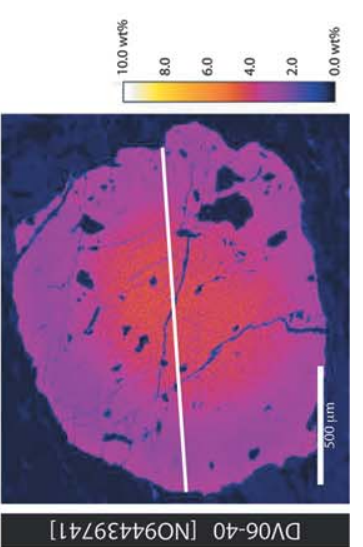

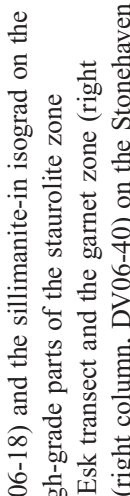

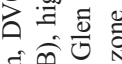

音孛焉

용

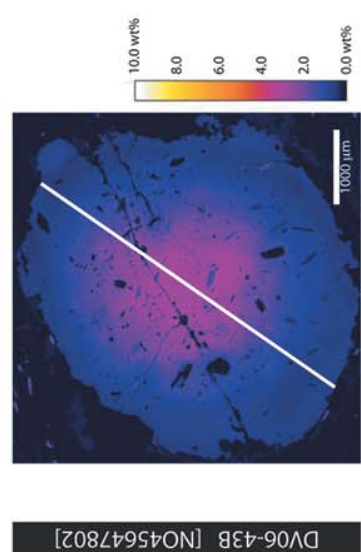

造命寻

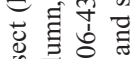

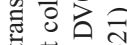

ฮ .

펑 궁

总总志

\& 5

ㅇํㅇㅎㅠ

‡ $\Xi$

ㅇํㅇ ฮี

吾

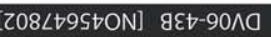
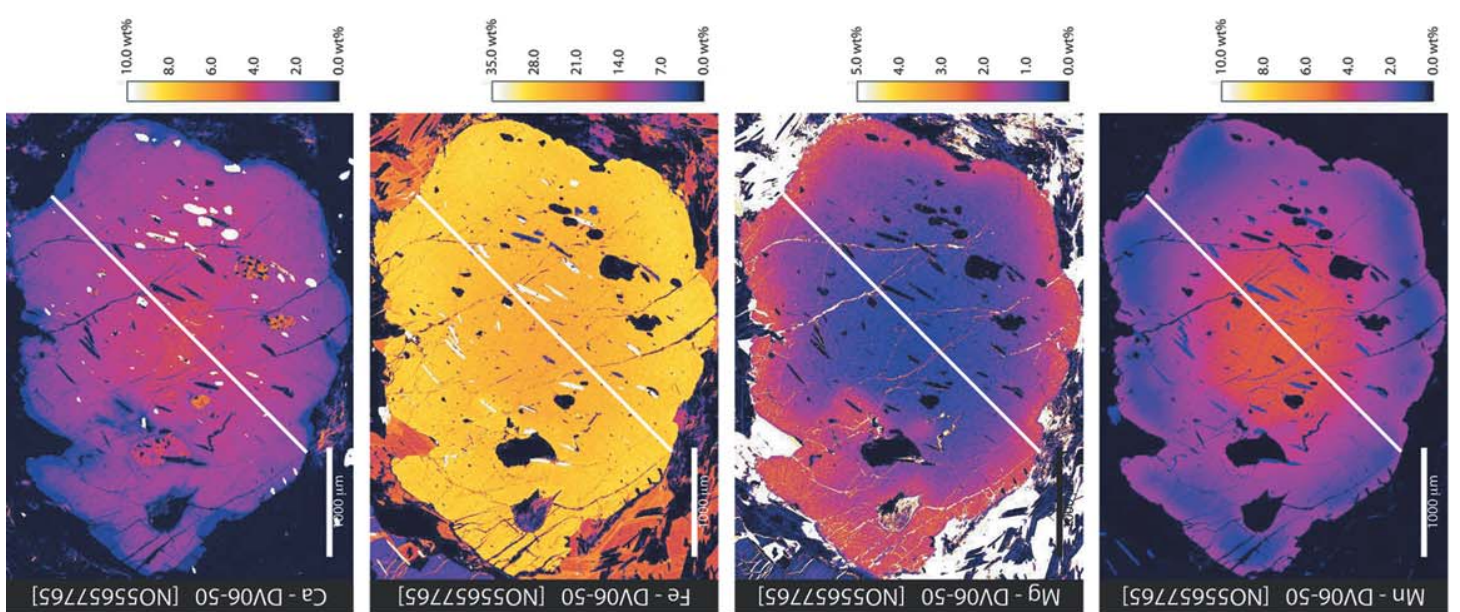

응

|

递官

를

吅范

울 뭉

究

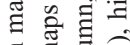

흐릉

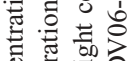

ฮี

ठี ญ. छ

今 0 링

为就击

क ते

요유

용.
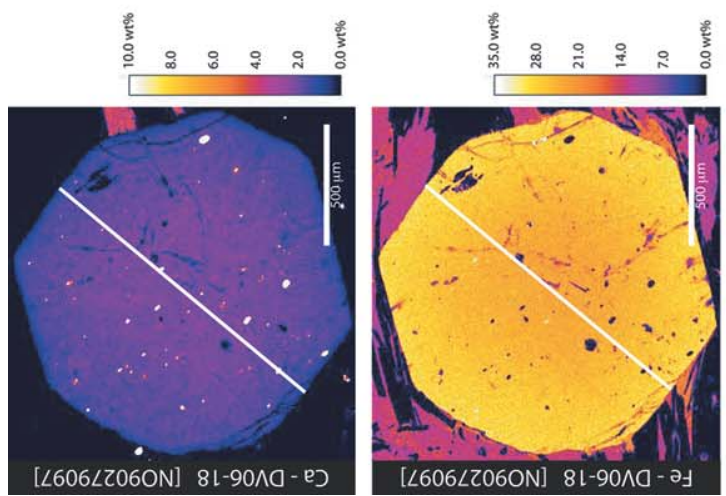

苞它兽产

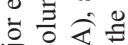

画 合

웡ㅇํㅇ

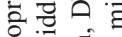

总节主

寻

흘 는

政

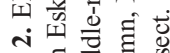

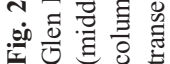



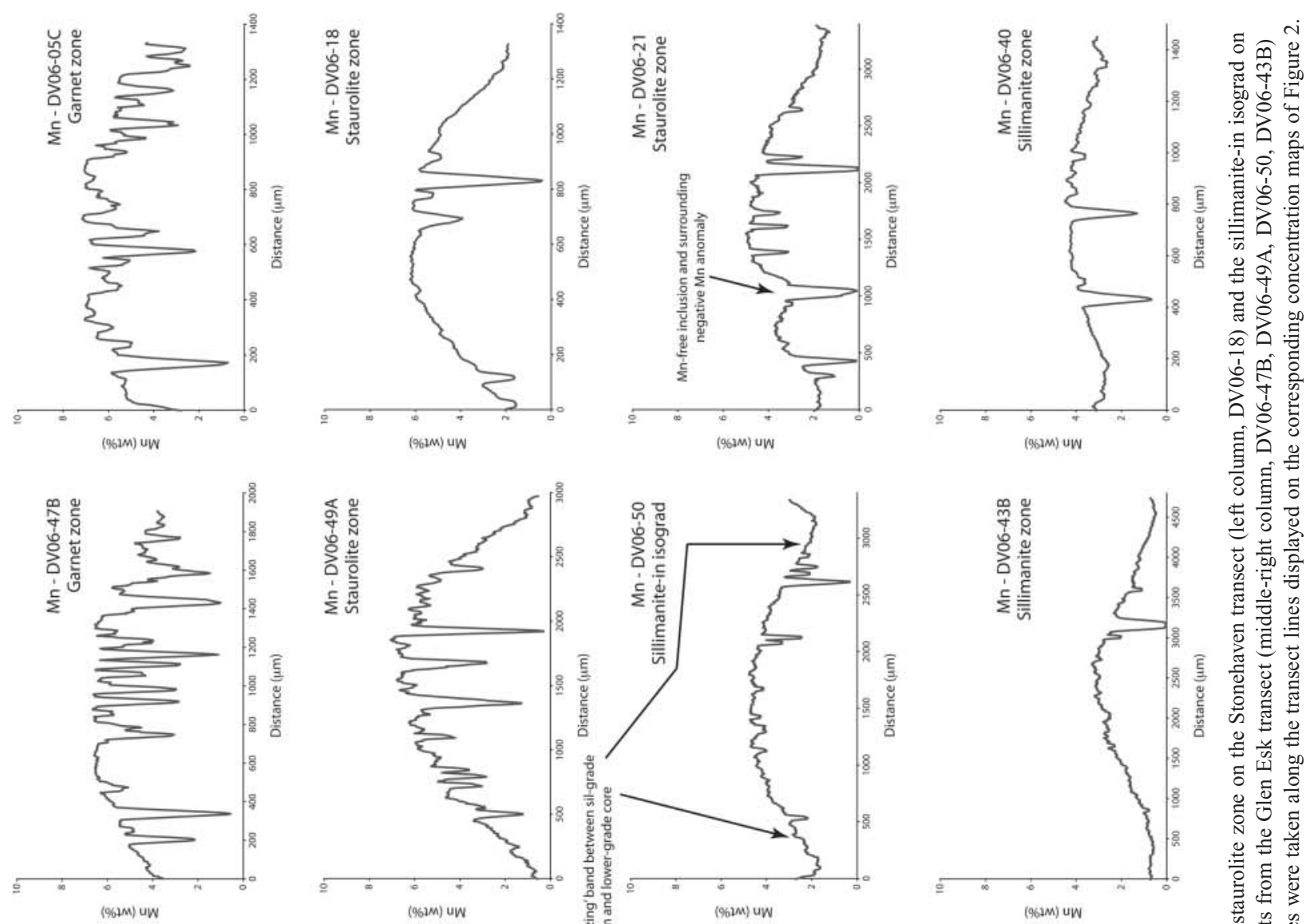

言书
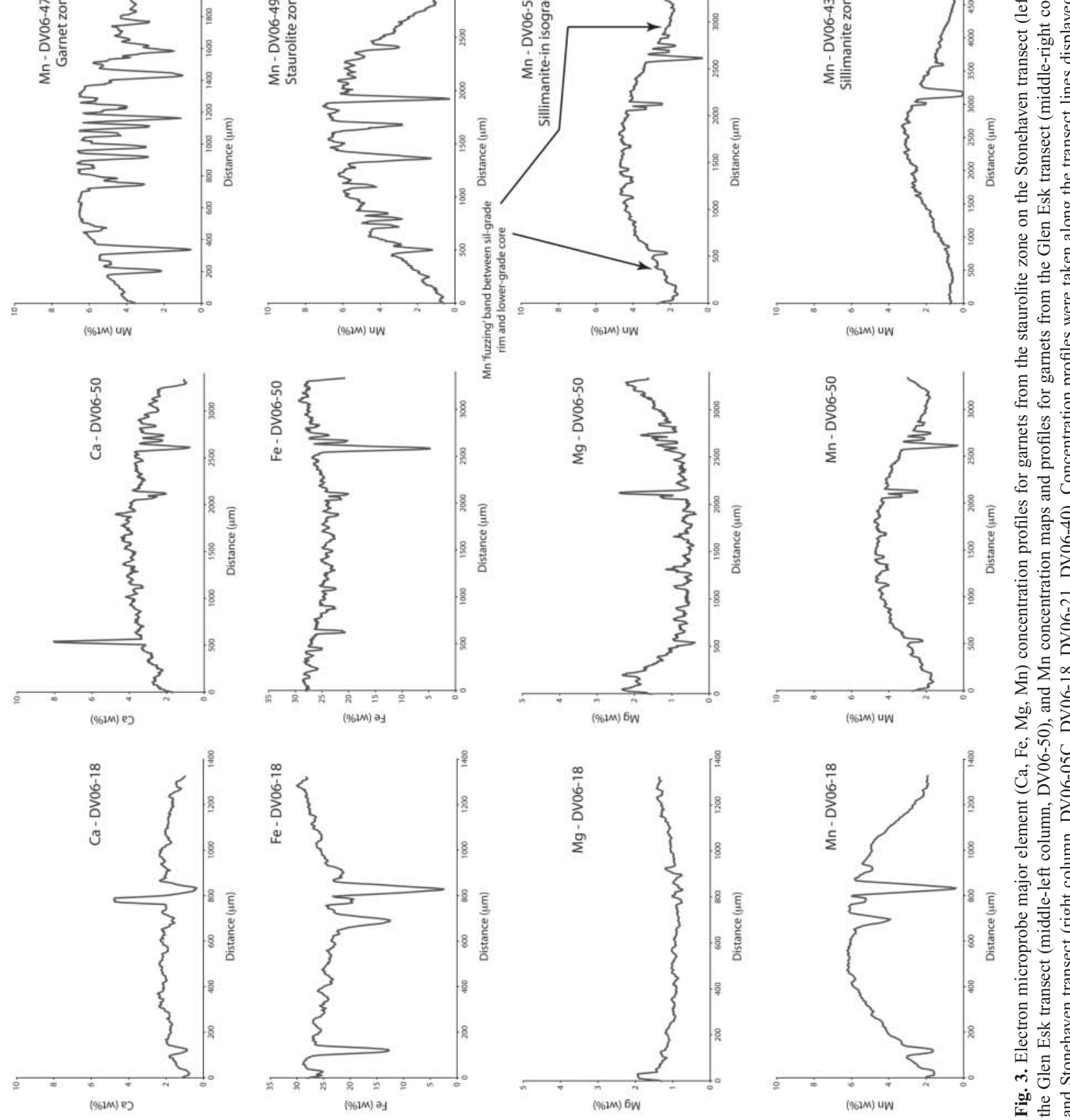

ฐ

원

总造

논 뭉

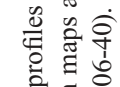

它莒

䟖

気

०.

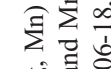

䑶

कि

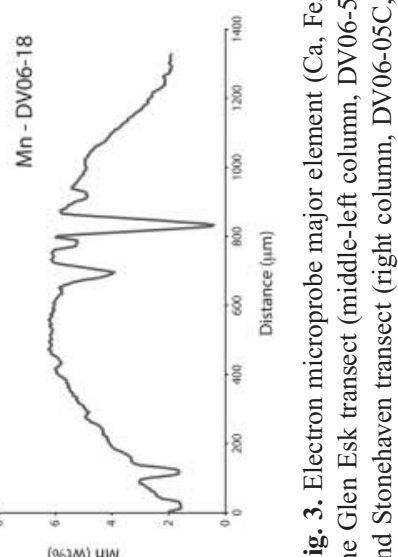


between core and rim domains (see DV06-50, Figs 2 and 3). These 'fuzzing bands' are associated with an upturn in $\mathrm{Mg} / \mathrm{Fe}$ (see DV06-50, column 2, Fig. 3). This observation is consistent with the 'fuzzing bands' marking the point of new growth of compositionally distinct garnet during prograde metamorphism, rather than it marking a compositional break created by retrograde Mn resorption (cf. Kohn \& Spear 2000).

Irregularities in $\mathrm{Mn}$ and/or $\mathrm{Ca}$ concentration profiles are apparent in the garnets analysed by LA-ICP-MS (Fig. 4). These irregularities may reflect secondary compositional zoning in garnet, defined by the presence of discrete compositional domains, or they may reflect the influence of inclusions in garnet in the analyses. Congruence between $\mathrm{Al}$ and $\mathrm{Mn}$ profile behaviour for samples DV06-05C, DV06-49A, DV06-21 and DV06-40 suggests that irregularities in $\mathrm{Mn}$ and $\mathrm{Ca}$ composition profiles for these garnets have their origin in the presence of inclusions (Fig. 4). However, a lack of congruence between $\mathrm{Al}$ and $\mathrm{Mn}$ and/or $\mathrm{Ca}$ profile behaviour for samples DV06-47B, DV06-18, DV06-50 and DV06-43B (Fig. 4) suggests that some of the irregularities in LA-ICP-MS Mn and/or Ca profiles for these garnets have their origins in a distinct compositional zoning pattern superimposed on the general grain-scale, core-rim zoning. Secondary compositional zoning is apparent in the compositional profiles for DV06-47B and DV06-18, defined by c. $250 \mu \mathrm{m}$ wide discrete compositional domains in $\mathrm{Mn}$ and Ca (Fig. 4). Sample DV0647B shows a very distinct secondary zoning pattern for both Mn and $\mathrm{Ca}$ (Fig. 4). In the case of DV06-18, the secondary compositional zoning pattern for $\mathrm{Mn}$ is more subtly superimposed on the general bell-shaped zoning than that for $\mathrm{Ca}$. Samples DV06-50 and DV06-43B display secondary compositional zoning patterns only in $\mathrm{Ca}$ and not in Mn (Fig. 4). Length scales of the discrete $\mathrm{Ca}$ zoning domains are of the order of $500 \mu \mathrm{m}$ for DV06-50 and 800-1000 $\mu \mathrm{m}$ for DV06-43B (Fig. 4).

Manganese-free mineral inclusions (quartz and white mica) are associated with low-concentration anomalies in some $\mathrm{Mn}$ maps. These features are manifested as core-ward deflections ('embayments') in garnet $\mathrm{Mn}$ concentration contours around large, Mn-free inclusions (or clusters of inclusions). Embayments are apparent in the Mn abundance maps for samples DV06-49A, DV06-21 and DV06-43B (Fig. 3). Figure 5 displays enlargements of these embayments for samples DV06-49A and DV06-21. Although such anomalies are rather pronounced in Mn maps, there are no corresponding anomalies in the equivalent $\mathrm{Ca}$ maps (Fig. 5). Low-Mn anomalies in the garnet maps, related to the presence of $\mathrm{Mn}$-free inclusions, are more localized on the core side than on the rim side, as is demonstrated by greater curvature in core-side deflections in $\mathrm{Mn}$ abundance about large Mn-free inclusions (see concentration profile for DV06-21 in Fig. 3). Asymmetry in concentration gradients around $\mathrm{Mn}$-free inclusions (or inclusion clusters) demonstrates a rim-side Mn concentration shadow. No such concentration shadow occurs in association with inclusions (or clusters of inclusions) in the equivalent $\mathrm{Ca}$ maps (Fig. 5).

\section{Yttrium and REE zoning in Barrovian garnets}

Yttrium and REE, because of their occurrence in garnet at lower concentrations, were investigated by LA-ICP-MS, which provided Mn, Y, La, Ce, Pr, Nd, Sm, Eu, Gd, Tb, Dy, Ho, Er, Tm, $\mathrm{Yb}$ and $\mathrm{Lu}$ abundance profiles for those garnets whose $\mathrm{Mn}$ composition maps and profiles are represented in Figure 3. Salient details of the yttrium and REE zoning discussion below are summarized in Table 1.

\section{Results}

The LA-ICP-MS profiles of Figure 6 provide a summary of the $\mathrm{Y}$ zoning results for the garnets analysed for $\mathrm{Mn}$ by electron microprobe. Garnets from samples DV06-50, DV06-43B, DV0618, DV06-21 and DV06-40 have elevated Y concentrations at the grain edge that define resorption textures. Like Mn concentration profiles from Barrovian garnets, some of the $\mathrm{Y}$ profiles have a bell-shaped form (DV06-47B, DV06-05C, DV06-18, DV06-40; Fig. 6). In those garnets that display a bell-shaped form, maximum Y concentrations vary from about 750 to $1050 \mathrm{ppm}$ and minimum values vary from around 100 to $150 \mathrm{ppm}$. Proportional variation in maximum element abundance across the analysed garnets with bell-shaped form is noticeably smaller for $\mathrm{Y}$ than for $\mathrm{Mn}$, as is the variation with increasing metamorphic grade in core-to-rim differences in element abundance (Fig. 6). However, the nature of $\mathrm{Y}$ zoning is not invariable among the Barrovian garnets that were analysed. Yttrium zoning in garnets from samples DV06-49A, DV06-50 and DV06-21 is minimal, whereas DV06-43B does not display any Y zonation (Fig. 6). Garnets that exhibit considerable zoning in $\mathrm{Y}$ display tight $\mathrm{Y}$ zoning with respect to Mn zoning (i.e. smaller Y-rich cores than the Mn-rich cores; Fig. 6), and it is expected that off-centre cuts will more greatly influence the nature of $\mathrm{Y}$ zoning displayed in garnet composition maps than that of $\mathrm{Mn}$ zoning (see Skora et al. 2006). Off-centre cuts can thus account for the discrepancy between garnets that show little or no zoning in Y (DV06-49A, DV06-50, DV06-43B, DV06-21; Fig. 6) and those that show clear zoning in Y (DV06-47B, DV06-05C, DV06-18, DV06-40; Fig. 6). Thus, those garnets that display clear Y zoning (DV0647B, DV06-05C, DV06-18, DV06-40) are also the most likely to represent central cuts (see Skora et al. 2006), and thereby offer the most robust data for interpretation.

The REE plot of Figure 7 provides a representative summary of the manner by which the REE vary across garnets of the Barrovian metamorphic series. The heavy REE (HREE) display a strong decrease in their concentration from core to rim in samples that show significant Y zoning (e.g. DV06-18), forming bell-shaped element concentration profiles (Fig. 7). Figure 7 demonstrates congruence between $\mathrm{Y}$ and $\mathrm{HREE}(\mathrm{Yb})$ zoning in all garnets.

\section{Discussion}

\section{Length scales of Mn diffusion in garnet during the Barrovian metamorphism}

Manganese composition profiles from garnets of the Barrovian metamorphic series display bell-shaped forms consistent with garnet growth by Rayleigh fractionation from a homogeneous growth reservoir (see Hollister 1966). Diffusion-related modification of bell-shaped profiles, unlike that of step profiles, cannot be recognized on profile geometry alone, as the process of diffusion acts to alter curvature but not the basic form of the profiles. The first challenge for application of geospeedometry to the garnets of the Barrovian metamorphic series is to recognize diffusionrelated textures from compositional features acquired during their original growth.

Jaffe (1951) demonstrated a clear correlation between Mn and $\mathrm{Y}$ abundance in garnet, whereby $\mathrm{Y}^{3+} \mathrm{Al}^{3+}$ will readily substitute for $\mathrm{Mn}^{2+} \mathrm{Si}^{4+}$. According to the work of Jaffe (1951), and more recently Lanzirotti (1995) and Pyle \& Spear (1999), Y growth zoning in garnet will superficially mimic that for Mn. Manganese varies in both core and rim abundance, for very little change in the $\mathrm{Y}$ zoning, with increasing metamorphic grade in garnets that 

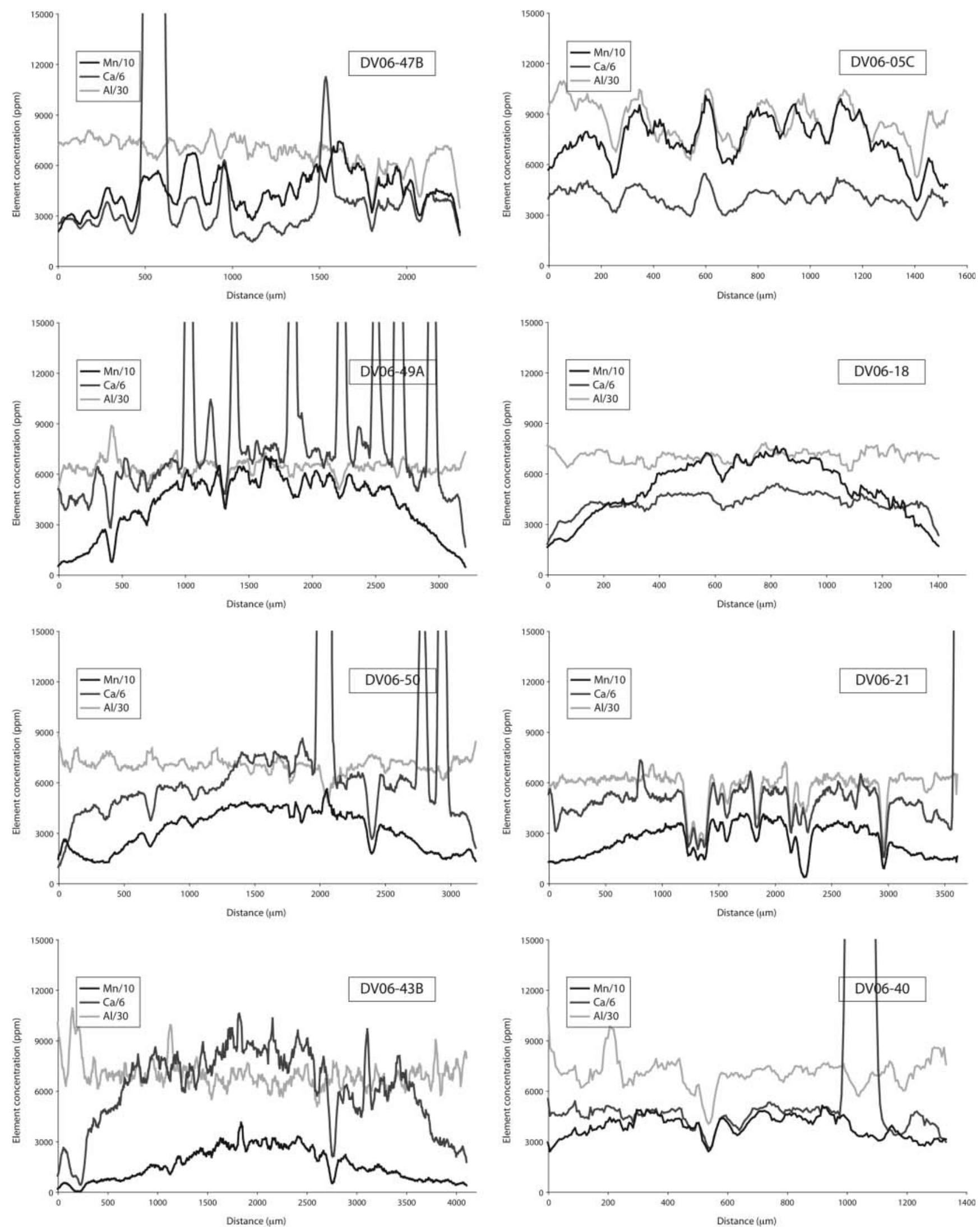

Fig. 4. LA-ICP-MS Al, Ca and Mn concentration profiles for garnets from the garnet zone (DV06-47B), the high-grade parts of the staurolite zone (DV0649A), the sillimanite-in isograd (DV06-50) and the sillimanite zone (DV06-43B) on the Glen Esk transect and the garnet zone (DV06-05C), the middle of the staurolite zone (DV06-18), the high-grade parts of the staurolite zone (DV06-21) and the sillimanite zone (DV06-40) on the Stonehaven transect. Factors have been applied to the concentration of each element to allow direct comparison of the form of the profiles. 

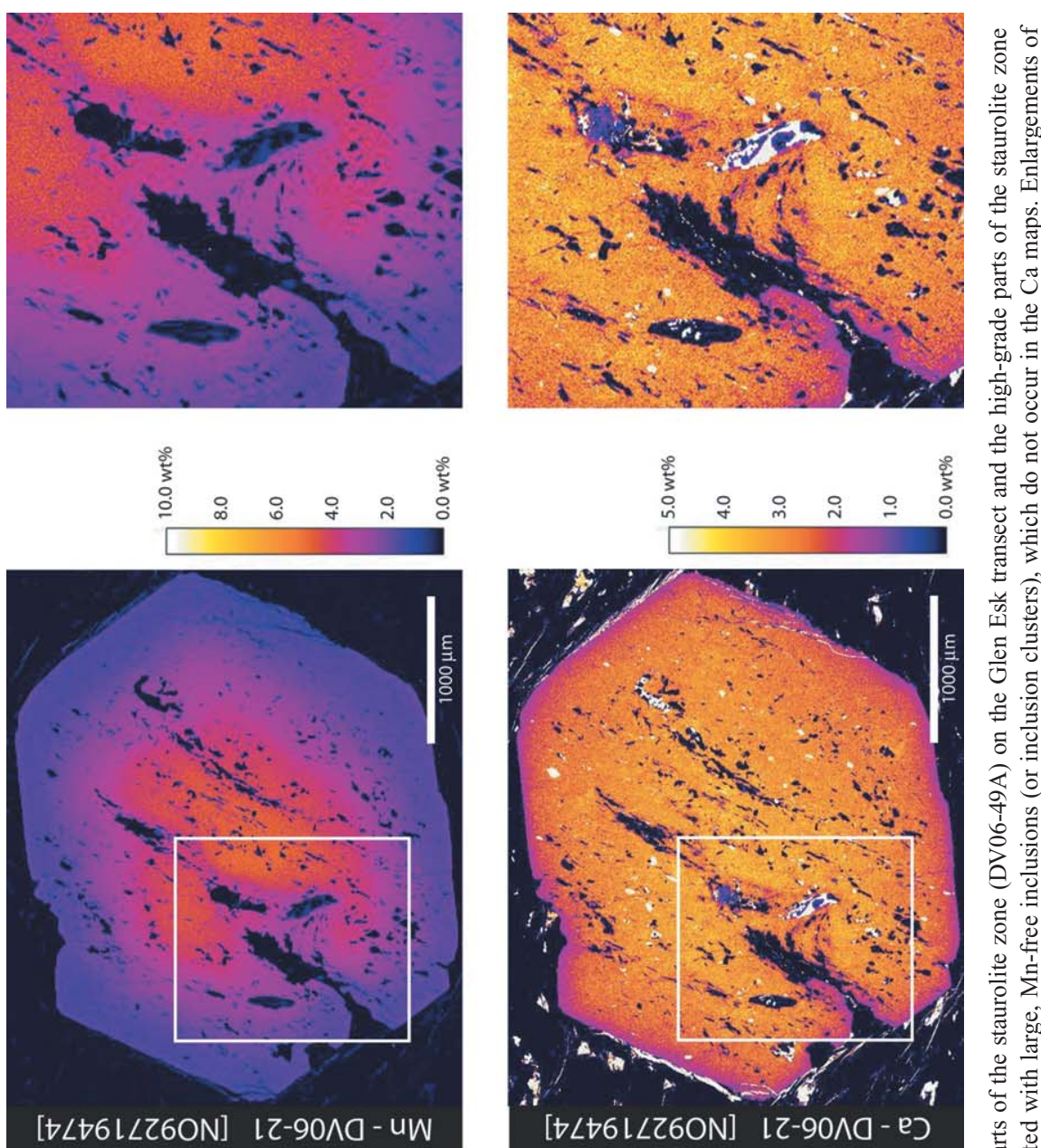

$\stackrel{0}{\rightleftarrows} \stackrel{\circ}{\circ}$

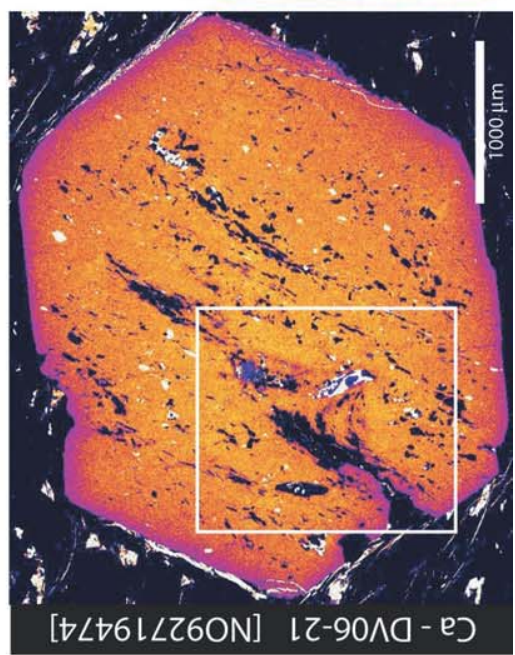

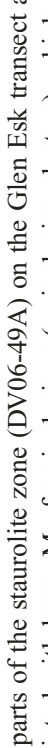
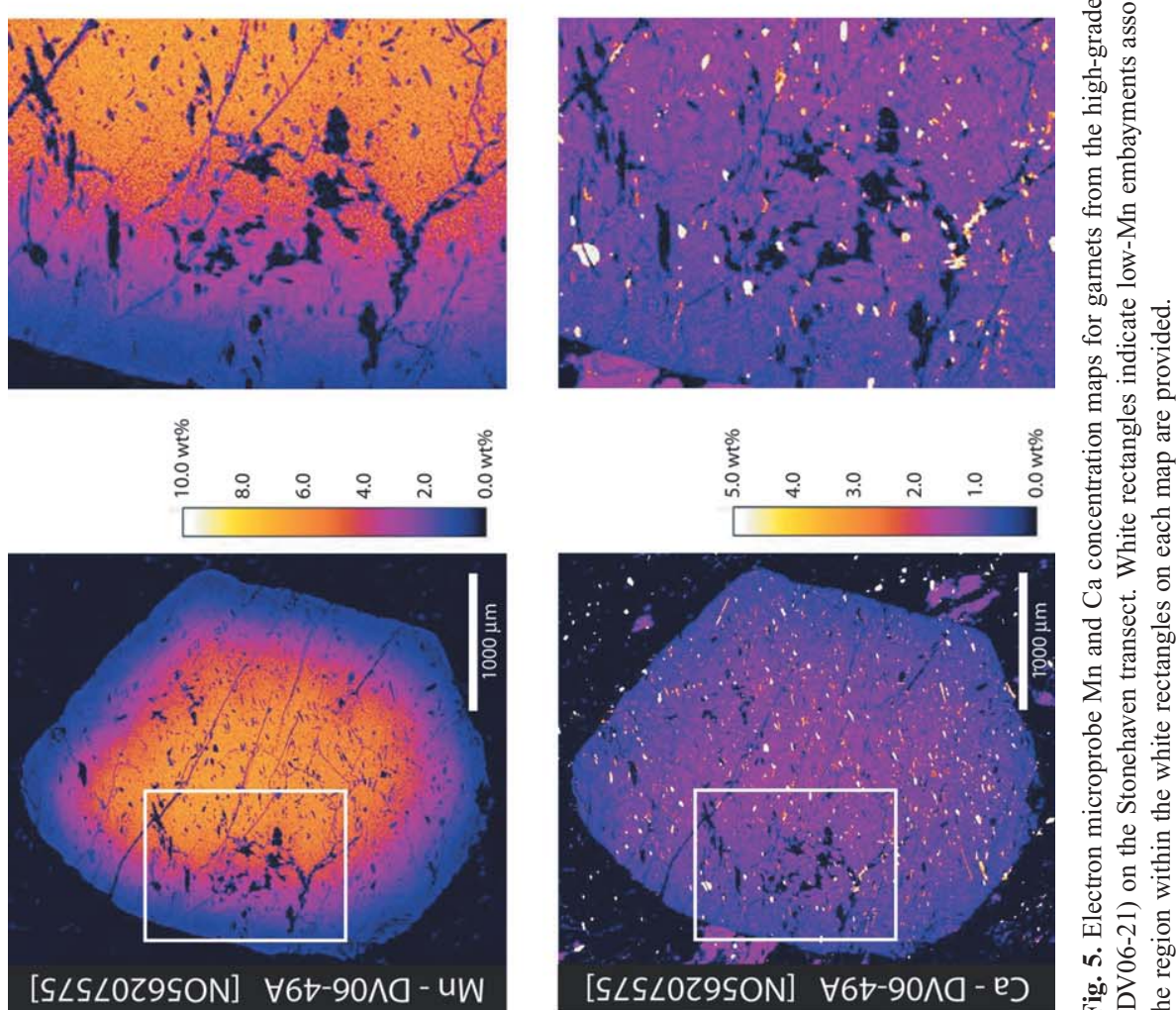

[SLSLOZ9SON] $\forall 6 t-90 \wedge 0-$ UW
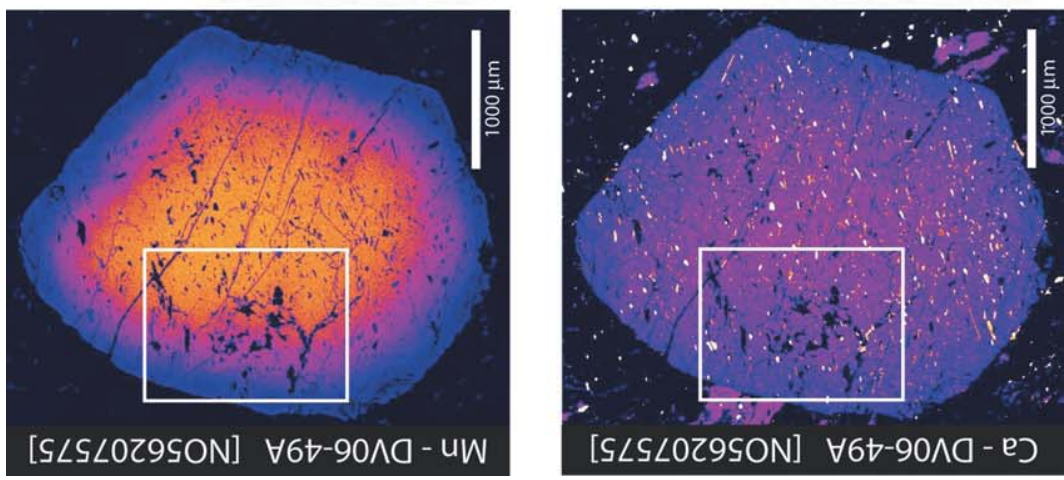

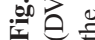



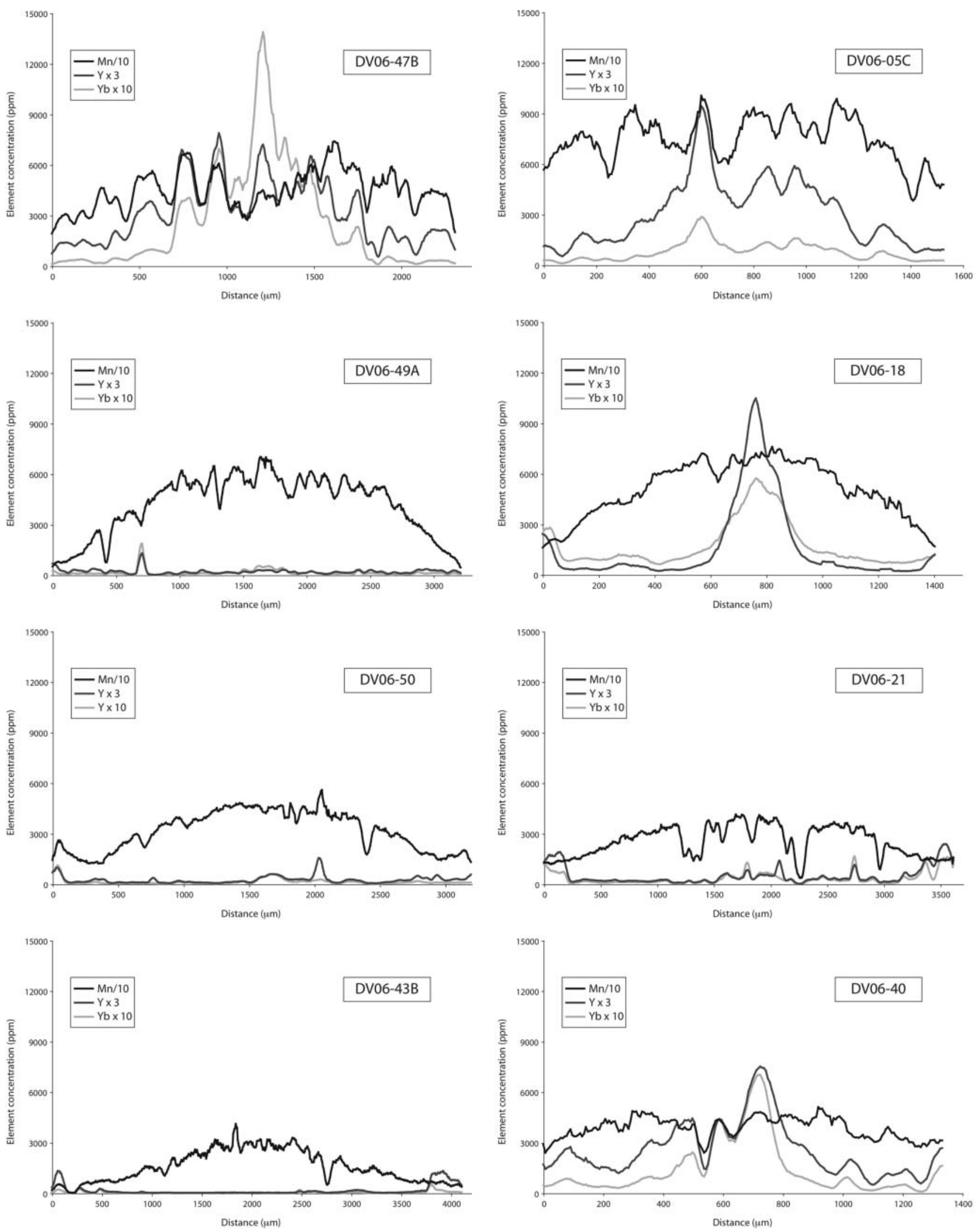

Fig. 6. LA-ICP-MS Mn, Y and Yb concentration profiles for garnets from the garnet zone (DV06-47B), the high-grade parts of the staurolite zone (DV0649A), the sillimanite-in isograd (DV06-50) and the sillimanite zone (DV06-43B) on the Glen Esk transect and the garnet zone (DV06-05C), the middle of the staurolite zone (DV06-18), the high-grade parts of the staurolite zone (DV06-21) and the sillimanite zone (DV06-40) on the Stonehaven transect. Factors have been applied to the concentration of each element to allow direct comparison of the form of the profiles. 


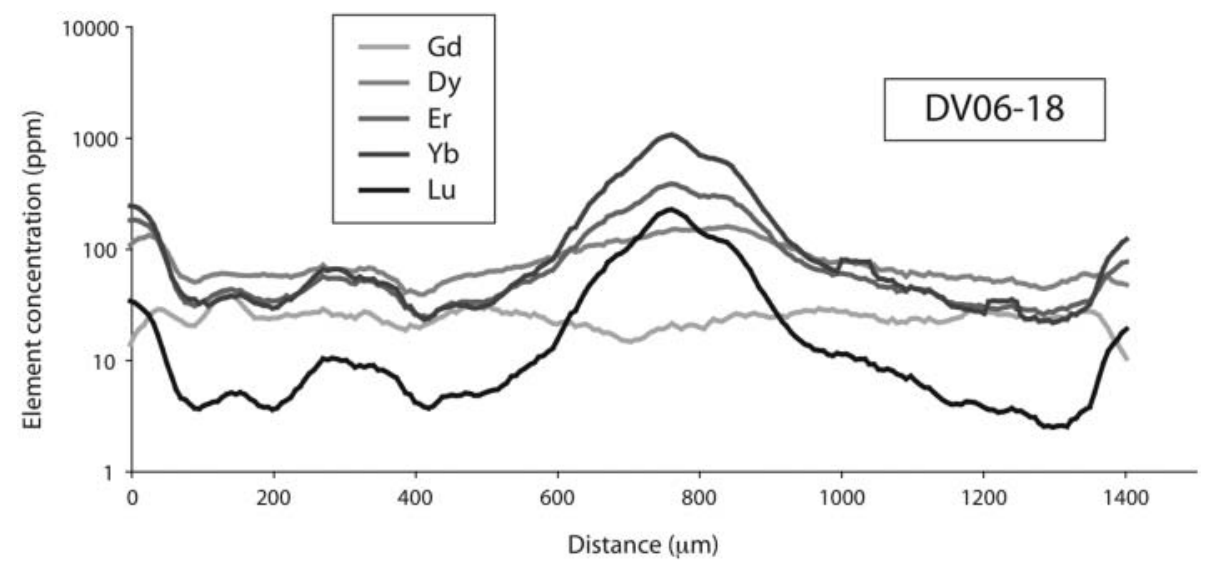

Fig. 7. LA-ICP-MS REE (Gd, Dy, Er, Yb and $\mathrm{Lu}$ ) concentration profiles for a garnet from the low-grade parts of the staurolite zone (DV06-18) on the Stonehaven transect. show clear bell-shaped zoning in Y (DV06-47B, DV06-05C, DV06-18, DV06-40; Fig. 6). Considering the work of Jaffe (1951), Lanzirotti (1995) and Pyle \& Spear (1999), one might be inclined to appeal to syn- to post-growth $\mathrm{Mn}$ diffusion (at temperatures too low to cause movement of the larger and higher-charged $\mathrm{Y}$ atoms) as the cause of loss of Mn from garnet cores and accumulation of $\mathrm{Mn}$ in garnet rims (flattening of $\mathrm{Mn}$ profiles) in Barrovian garnets with increasing metamorphic grade. However, the situation is appreciably more complex. Chernoff \& Carlson (1999) showed that trace element concentrations in garnet can vary dramatically over small distances and proposed that the rate of breakdown of minerals rich in these elements during prograde heating outstrips the sluggish diffusion rates of these elements through the rock matrix. In the same year, Pyle \& Spear (1999) were able to demonstrate that the presence of xenotime $\left(\mathrm{YPO}_{4}\right)$ directly influences $\mathrm{Y}$ abundance patterns in garnet and can thereby account for abrupt variations in $\mathrm{Y}$ zoning patterns with variation in metamorphic grade.

A similar case could be made for the origin of across-grade variation in $\mathrm{Mn}$ zoning by garnet growth in the presence or absence of Mn-bearing minerals. However, where Y displays significantly greater compatibility in xenotime than garnet (Pyle \& Spear 1999), $\mathrm{Mn}$ is more compatible in garnet than other coexisting phases in pelites (Thompson 1976; Woodsworth 1977). Pownceby et al. (1987) gave the order of compatibility of $\mathrm{Mn}$ in commonly occurring phases in pelites as garnet $>$ ilmenite $\gg$ staurolite $>$ cordierite $>$ biotite. Ilmenite, the only commonly occurring phase capable of sequestering $\mathrm{Mn}$ in significant quantities, accounts for a minor proportion $(<1-3$ modal $\%$ ) of Barrovian pelitic units with respect to that constituted by garnet (5-15 modal \%). A number of generations of garnet growth can be distinguished in the high-grade zones of the Barrovian metamorphic series (McLellan 1985; Baxter et al. 2002). Despite the preference of $\mathrm{Mn}$ for garnet over other coexisting phases, the relative timing of nucleation of a garnet crystal with respect to other garnet crystals in the rock may influence geochemical zonation.

Varying metamorphic growth histories across metamorphic grade will strongly influence grain-scale Mn zoning patterns in garnet, making characterization of initial grain-scale Mn profiles impracticable, even with knowledge of $\mathrm{Y}$ zoning patterns in the same garnet. Thus, a robust estimate for the length scales of $\mathrm{Mn}$ diffusion during metamorphism cannot be obtained from variation in grain-scale $\mathrm{Mn}$ and $\mathrm{Y}$ zoning patterns across metamorphic grade and evidence for the length scales of Mn diffusion during the Barrovian metamorphism must be found in other diffusionrelated features.
Secondary compositional zoning in $\mathrm{Ca}$, superimposed on the general grain-scale bell-shaped zoning, is apparent in concentration profiles for some garnets from the garnet, staurolite and sillimanite zone of the Barrovian metamorphic series (Fig. 4). Length scales of discrete compositional domains defined by the secondary compositional zoning in $\mathrm{Ca}$ are of the order of $250 \mu \mathrm{m}$ for samples DV06-47B and DV06-18, $500 \mu \mathrm{m}$ for DV0650 and $1000 \mu \mathrm{m}$ for sample DV06-43B (Fig. 4). Samples displaying secondary compositional zoning in $\mathrm{Ca}$ display equivalent zoning in Mn over identical length scales for DV06-47B from the garnet zone and DV06-18 from the staurolite zone. However, samples from the sillimanite zone (DV067-50, DV0643B) show no such corresponding secondary compositional zoning in $\mathrm{Ca}$ (Fig. 4).

The absence of a corresponding secondary compositional zoning in $\mathrm{Mn}$ in sillimanite-grade samples that display secondary compositional zoning in $\mathrm{Ca}$ may be associated with metamorphic grade dependence on $\mathrm{Mn}$ and $\mathrm{Ca}$ growth systematics during the Barrovian metamorphism. Alternatively, it may be related to loss of an original equivalent compositional zoning pattern in $\mathrm{Mn}$ to that in $\mathrm{Ca}$ by diffusion of $\mathrm{Mn}$ over length scales larger than those of the discrete compositional domains in $\mathrm{Ca}$ (i.e. length scales greater than $1000 \mu \mathrm{m}$ for DV06-43B). Notwithstanding the influence of metamorphic growth histories on element zoning patterns, it is unlikely that the nature of $\mathrm{Mn}$ v. Ca growth patterns would vary so radically across metamorphic grade given that growth of large sillimanite-grade Barrovian garnets began under garnet- or staurolite-grade conditions (see Baxter et al. 2002; DV06-50). Calcium is significantly slower diffusing than Mn (see Table 2). We take the relative variation in secondary compositional zoning in $\mathrm{Ca}$ and $\mathrm{Mn}$ to indicate $\mathrm{Mn}$ diffusion during the sillimanite-grade metamorphism over length scales in excess of $1000 \mu \mathrm{m}$, for little diffusion of $\mathrm{Ca}$.

Concentration shadows occur rim-side of large Mn-free inclusions (or inclusion clusters), but are not apparent in the compositional maps for slower-diffusing Ca (Fig. 5). The presence of Mn concentration shadows rim-side of $\mathrm{Mn}$-free inclusions (or inclusion clusters), and the lack of such features in the equivalent $\mathrm{Ca}$ maps, is consistent with significant core-to-rim movement of $\mathrm{Mn}$ (a radial Mn flux) during metamorphism, for negligible $\mathrm{Ca}$ movement. The conceptual model summarized in Figure 8 illustrates the scenario hypothesized for development of the Mn concentration shadows rim-side of $\mathrm{Mn}$-free inclusions. In the Barrovian garnets, these manganese concentration shadows display length scales of the order of $300 \mu \mathrm{m}$ (apparent in the concentration profile for DV06-21; Fig. 3) and must be related to rim-ward movement of $\mathrm{Mn}$ on larger scales. We take diffusion to 
have occurred over length scales of the order of $1000 \mu \mathrm{m}$ in high-grade garnets during the Barrovian metamorphic event. Radial movement of Mn over these length scales can account for some degree of the up-metamorphic-grade homogenization in Mn concentrations that has been observed for Barrovian garnets (see Atherton 1968; Dempster 1985).

Thus, two robust lines of evidence exist in support of diffusion of $\mathrm{Mn}$ in garnet over $c .1000 \mu \mathrm{m}$ length scales during metamorphism of the higher-grade units of the Barrovian metamorphic series: (1) the lack of discrete (c. $1000 \mu \mathrm{m})$ compositional domains defined by $\mathrm{Mn}$ in garnets of the sillimanite zone that display discrete $(c .1000 \mu \mathrm{m})$ compositional domains defined by $\mathrm{Ca}$; (2) the presence of compositional shadows rim-side of large $\mathrm{Mn}$-free inclusions (or inclusion clusters).

\section{Major element diffusion in garnet}

Any attempt to extract information from diffusion profiles preserved in natural rocks requires knowledge of the rates at which diffusion proceeds. Self-diffusion of a chemical species in garnet is dependent on the diffusion coefficient $(D)$. The Arrhenius equation describes the manner by which the diffusion coefficient varies with temperature $(T)$ and pressure $(P)$ :

$$
D=D_{0} \exp \left[\frac{-\left(Q+P \Delta V^{+}\right)}{R T}\right]
$$

where $D_{0}$ represents a constant known as the frequency factor, $Q$ is the Arrhenius activation energy, $\Delta V^{+}$is the activation volume and $R$ is the universal gas constant. A simplified form of the Arrhenius equation (equation (1)), which is dependent only on $T$ and not $P$, is often used:

$$
D=D_{0} \exp \left(\frac{-E_{\mathrm{a}}}{R T}\right)
$$

where $E_{\mathrm{a}}$ is the activation energy.

A number of studies have attempted to quantify the Arrhenius parameters that govern major element diffusion in garnet. Studies have taken either an experimental approach or an empirical approach. Efforts to quantify the variables that describe major element diffusion in garnet have principally involved experimental studies on garnets of varying composition (e.g. Freer 1979; Cygan \& Lasaga 1985; Loomis et al. 1985; Chakraborty \& Ganguly 1992; Schwandt et al. 1995, 1996; Ganguly et al. 1998; Freer \& Edwards 1999; Vielzeuf et al. 2007). Experimental work concerning the diffusion of commonly occurring divalent cationic species $(\mathrm{Ca}, \mathrm{Fe}, \mathrm{Mg}, \mathrm{Mn})$ in garnet has been carried out at pressures of between $1 \mathrm{bar}$ and $40 \mathrm{kbar}$ and temperatures of $800-1400{ }^{\circ} \mathrm{C}$. Experimentally derived values for the Arrhenius parameters that govern major element diffusion in garnet are summarized in Table 2. To ensure that meaningful data can be obtained over reasonable run times, garnet diffusion experiments must be carried out at relatively high temperatures. Downtemperature extrapolation of experimental results to conditions relevant to amphibolite-grade metamorphism can introduce significant uncertainties, as the large range of values for diffusivity (D) of the different cationic species, at conditions of $T=670{ }^{\circ} \mathrm{C}$ and $P=6.1 \mathrm{kbar}$, would testify (Table 2 ).

Studies carried out on natural garnets proceed by characterization of compositional zoning in garnets and back calculation of the diffusion parameters that will allow production of the features observed under temperature, pressure and time constraints. For most lithologies, relatively precise and robust estimates for peak 

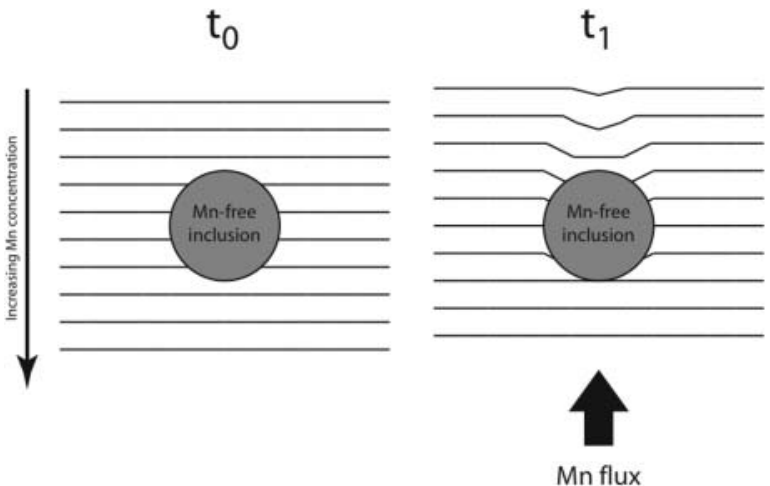

metamorphic temperatures and pressures can be made on the basis of metamorphic petrology and/or whole-rock and mineral geochemistry. The temperature and pressure history during metamorphism, however, is much harder to characterize.

Studies on natural garnets have generally yielded qualitative or semi-quantitative results (e.g. Yardley 1977; Dempster 1985; Ayres \& Vance 1997; Kohn 2004). However, a rather comprehensive study carried out by Carlson (2006) presented firm quantitative recommendations for the values of the parameters that govern major element diffusion in garnet (Table 2). Carlson (2006), using numerical modelling techniques to replicate diffusion profiles preserved in partially resorbed natural garnets from the Llano Uplift, Texas, and the metamorphic aureole of the Makhavinekh Lake Pluton, Labrador, constrained $\mathrm{Ca}, \mathrm{Fe}, \mathrm{Mg}$ and $\mathrm{Mn}$ diffusion behaviour in garnet at low temperatures, thereby estimating values for the constants of diffusion at temperatures and pressures commonly encountered in amphibolite-facies regional metamorphism. Studies on natural garnets such as that of Carlson (2006) adopt an empirical approach, which introduces uncertainties through the inherent assumption that the pressure-temperature-time $(P-T-t)$ paths used for the modelling reflect real $P-T-t$ histories. Such uncertainties can produce regular offsets in the diffusivity constants, which result in systematically high (or low) estimates, from geospeedometry, for the time scales of diffusion (and the duration of metamorphism). To adopt one parameter set from the literature at the expense of all others may prove perilous with current degrees of uncertainty in the Arrhenius parameters that govern major element diffusion in garnet (Table 2).

\section{Thermal time scales for the Barrovian metamorphism}

Ague \& Baxter (2007) recognized c. $100 \mu \mathrm{m}$ length scale, diffusion-related modification of major-element step profiles between a sillimanite-grade rim and lower-grade core in garnet from the Barrovian metamorphic series. Sample DV06-50 displays evidence for an equivalent, $c .100 \mu \mathrm{m}$ wide 'fuzzing band' that separates a sillimanite-grade rim and lower-grade core (Figs 2 and 3).

Late sillimanite growth in the highest-grade parts of the Barrovian metamorphic series (see Chinner 1966; Harte \& Hudson 1979) represents a spatially limited thermal overprint on the regional metamorphic pattern. With evidence of heat exchange over two length scales in the highest-grade parts of the Barrovian metamorphic series, one might expect bimodality in the length scale of features associated with Barrovian-age chemical diffusion. The $100 \mu \mathrm{m}$ diffusion features between sillimanite-grade core domains and lower-grade rim domains appear to represent evidence of diffusion related to the late sillimanite overprint, not the regional thermal event. Diffusion of the order of $1000 \mu \mathrm{m}$ and up-metamorphic-grade homogenization $t_{2}$

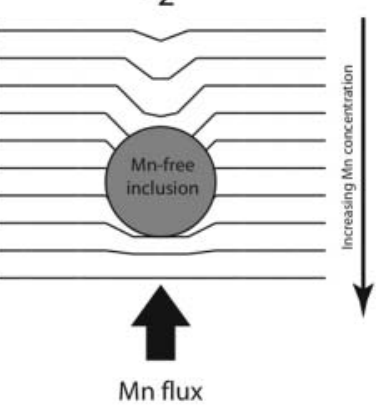

Fig. 8. Conceptual model for the development of Mn concentration shadows behind large Mn-free inclusions during radial movement of Mn by diffusion processes. Horizontal lines signify $\mathrm{Mn}$ concentration isopleths. The labels $\mathrm{t}_{0}, \mathrm{t}_{1}$ and $t_{2}$ refer to increasing time steps, respectively, during the diffusion process. of garnet compositions are features in favour of larger-scale chemical diffusion during heating responsible for the regional metamorphic pattern.

Metamorphic $T$ and $P$ within the sillimanite zone of the Barrovian metamorphic series attained values of the order of $670{ }^{\circ} \mathrm{C}$ and 6 kbar, respectively (Harte \& Hudson 1979; Baker 1985). With knowledge of the starting Mn concentration geometry and the diffusion parameters for $\mathrm{Mn}$ in almandine, one could use forward models to determine the heating durations required to produce the modified Mn profiles observed for the sillimanitegrade garnets. However, published Arrhenius parameters for the diffusion of $\mathrm{Mn}$ in almandine give a spread of over five orders of magnitude for diffusivity at the temperatures and pressures of metamorphism in the sillimanite zone of the Barrovian metamorphic series $\left(T=670{ }^{\circ} \mathrm{C}, P=6.1 \mathrm{kbar}\right.$; Table 2). Experiments attempting to quantify diffusion parameters for $\mathrm{Mn}$ in garnet must be carried out at high temperatures, and down-temperature extrapolation of diffusion data to the conditions appropriate to metamorphism can introduce errors. Alternative approaches that employ element zoning preserved within natural garnets harbour uncertainty as a result of implicit assumptions regarding the $P-T-t$ history for the rock mass.

A lack of robust estimates for Mn-in-almandine diffusivity under appropriate metamorphic conditions limits the application of $\mathrm{Mn}$ geospeedometry to estimate metamorphic durations in absolute terms. Notably, however, the approach is still valid for relative heat duration comparisons. For Fickian diffusion, the square of the length scale of a diffusively modified region $(L)$ is proportional to the time scale of diffusion responsible $(t)$, multiplied by the system diffusivity $(D)$ :

$$
L^{2} \propto D t .
$$

According to equation (3), diffusion features developed under similar pressure and temperature conditions within the same system, which differ in length scale by an order of magnitude, must have developed as the result of diffusion processes that operated over time scales that differ by two orders of magnitude.

Viete et al. (2010b) used forward modelling of Ar diffusion to match observed variations in white mica ${ }^{40} \mathrm{Ar} /{ }^{39} \mathrm{Ar}$ step-heating spectra with increasing metamorphic grade, and thereby estimated the duration for the Barrovian thermal event in the biotite zone at between 1 and $4.5 \mathrm{Ma}$. The South Mayo Trough of western Ireland preserves a detailed record of activity during Grampian orogenesis in Ireland. On mineral provenance of the biostratigraphically constrained South Mayo Trough sediments, Dewey \& Mange (1999) estimated that Barrovian-type metamorphism at Connemara, western Ireland, the Irish equivalent of the Barrovian metamorphism in Scotland (Soper et al. 1999), persisted for between 2 and $10 \mathrm{Ma}$. Reverdatto \& Polyansky 
(2004) modelled crustal heating (and regional metamorphism) as the result of gabbro intrusion at Connemara, Ireland, and estimated that the associated heat anomaly would persist for 5$6 \mathrm{Ma}$. The work of Dewey \& Mange (1999), Reverdatto \& Polyansky (2004) and Viete et al. (2010b) is in agreement with thermal time scales for the regional metamorphism of the order of a few million years.

On the basis of results of modelling of $\mathrm{Sr}$ diffusion profiles in apatite, Ague \& Baxter (2007) recently proposed shorter time scales for the Barrovian regional metamorphism. They argued that the Barrovian metamorphic series records a time-integrated peak metamorphic duration of less than $1 \mathrm{Ma}$. Conductive dissipation of metamorphic heat from a c. 5-10 km thick sequence such as the Barrovian metamorphic series requires thermal durations in excess of $1 \mathrm{Ma}$ (see Viete et al. 2010b). Ague \& Baxter (2007) explained the reduced durations for conductive dissipation their model requires by exhumation of the Barrovian metamorphic series to the Earth's surface while it was 'hot'. The operation of such a mechanism should have been marked by overgrowth of Barrovian sillimanite by andalusite, but the Barrovian metamorphic series do not record such a feature (see Viete et al. 2010b). Uncertainty in the Cherniak \& Ryerson (1993) Sr-in-apatite diffusion parameters adopted by Ague \& Baxter (2007) for their diffusion modelling can account for metamorphic durations over an order of magnitude greater than those that they proposed. Neglecting issues associated with uncertainty in the experimental determinations for the parameters that govern $\mathrm{Sr}$ diffusion in apatite, the effects of additional factors such as diffusion volume need also to be taken into consideration. To illustrate this point, data from Cherniak \& Ryerson (1993) can be entered into Dodson's formula (Dodson 1973) to provide estimates of closure temperature at specified cooling rates. Here we consider a cooling rate of $30{ }^{\circ} \mathrm{C} \mathrm{Ma}^{-1}$, in a slab thickness of $100 \mu \mathrm{m}$. For $c$-parallel diffusion, diffusion closure then occurs in the range $600-650{ }^{\circ} \mathrm{C}$ for $Q=296 \mathrm{~kJ} \mathrm{~mol}^{-1}, D_{0}=1.2 \times$ $10^{-6} \mathrm{~m}^{2} \mathrm{~s}^{-1}$, with pressure varied over the range $0-10 \mathrm{kbar}$ and activation volume varied over the range 0 to $17 \times$ $10^{-6} \mathrm{~m}^{3} \mathrm{~mol}^{-1}$. For $c$-perpendicular diffusion under the same conditions, estimates for the closure temperature vary from 640 to $690{ }^{\circ} \mathrm{C}$ for $Q=271 \mathrm{~kJ} \mathrm{~mol}^{-1}, D_{0}=2.4 \times 10^{-7} \mathrm{~m}^{2} \mathrm{~s}^{-1}$. These values are close to the maximum value of temperature estimated for the Barrovian metamorphic series and therefore repeating the modelling and simulation experiments described by Ague \& Baxter (2007) can produce order of magnitude variation in the thermal duration estimates. It appears that the Barrovian background regional metamorphism developed over a duration greater than a million years, most probably over a few million years.

The quadratic relation for the length scales and time scales of diffusion (equation (3)) dictates that if diffusion over c. $1000 \mu \mathrm{m}$ was the result of regional metamorphism over a few million years, the $c .100 \mu \mathrm{m} \mathrm{Mn}$ diffusion textures that occur between sillimanite-grade rims and lower-grade cores must have developed as the result of thermal episodes a few tens of thousands of years in duration. Thus it can be concluded that the temperature-time development of the Barrovian metamorphic series was at least bimodal on a local scale, and metamorphism probably involved a sequence of localized thermal excursions over a few tens of thousands of years in addition to the background regional thermal event over a few million years.

\section{Bimodal heating in Barrovian-type settings}

Regional metamorphism in association with numerous shortlived heating episodes is not a new concept. Wijbrans \&
McDougall (1988) and later Lister \& Baldwin (1993) reasoned that transient, localized metamorphic heating could account for heterogeneity in ${ }^{40} \mathrm{Ar} /{ }^{39} \mathrm{Ar}$ datasets and the preservation of 'old' ages in units that experienced partial recrystallization during metamorphism. Episodic heating models have been used to explain the origin of heterogeneous ${ }^{40} \mathrm{Ar} /{ }^{39} \mathrm{Ar}$ apparent age sets obtained for Barrovian metamorphism on the islands of Naxos (Wijbrans \& McDougall 1988) and Ios (Baldwin \& Lister 1998) of the Greek Cyclades and the D'Entrecasteaux Islands of New Guinea (Lister \& Baldwin 1993). In addition, sensitive highresolution ion microprobe $\mathrm{U} / \mathrm{Pb}$ work carried out on migmatites from Naxos by Keay et al. (2001) has demonstrated a number of distinct zircon overgrowth events associated with numerous brief metamorphic heating episodes (on Barrovian geotherms) spanning a period of about $4 \mathrm{Ma}$. On the basis of results of modelling to replicate $\mathrm{Sr}$ diffusion profiles in apatite and major element diffusion profiles in high-grade garnet from the Barrovian metamorphic series, Ague \& Baxter (2007) presented a model for episodic metamorphism of the classical Barrovian metamorphic series. According to their model, a short pulse of advective heating, or a number of short heat pulses, less than $1 \mathrm{Ma}$ in duration was superimposed on a regional heating regime related to thermal relaxation to form the Barrovian metamorphism.

Below we present a new model for the origin of the Barrovian regional metamorphism over bimodal time scales that has some similarities to those previously proposed (e.g. Wijbrans \& McDougall 1988; Lister \& Baldwin 1993; Ague \& Baxter 2007), but differs in one important aspect. Models previously presented for the origin of episodic metamorphism in Barrovian-type settings have treated episodic heating as a superficial overprint on a regional thermal regime controlled by thickening-related thermal relaxation (see England \& Thompson 1984); they are hybrid models, incorporating localized episodic heating (localized advection and/or heat production) and broader-scale heat sources.

In contrast to these hybrid models, our model holds the same mechanism (repeated, localized and episodic heat advection and/or production) responsible for thermal activity on all time scales relevant to the Barrovian metamorphism, from a few years to a few million years. Our model is born of the proposition that localized advective heating and/or heat production was not only responsible for the short time-scale thermal excursions (Ague \& Baxter 2007) during the Barrovian regional metamorphism, but also for the background regional metamorphic heating itself.

\section{A new model for thermal development of the Barrovian metamorphic series}

Episodic heating is in agreement with metamorphic heating models that predict development of a regional thermal regime as the sum of numerous short-lived heating episodes closely spaced in time. With continued heat contribution from small-scale heat sources, whose separate thermal impacts are spatially limited, a general broadening of the net thermal aureole is capable of producing the seemingly smooth regional metamorphic gradients that epitomize the Barrovian metamorphic series. As the Barrovian thermal regime evolved, regional heating could have assimilated the separate effects of small-scale heat sources in all cases but the very latest heating episodes. Preservation of a late, localized thermal overprint on the Barrovian regional metamorphic pattern, in accord with our episodic heating model, can account for the origin of the late sillimanite-grade overprint on 
the Barrovian metamorphic series (see Chinner 1966; Harte \& Hudson 1979) within the same heating scenario that produced the regional (biotite- to sillimanite-grade) metamorphism. Within our thermal model, the late-stage, short time-scale heating mechanism that produced the sillimanite-grade thermal overprint is identical to that responsible for the $c .100 \mu \mathrm{m} \mathrm{Mn}$ diffusion textures that overprint the $c .1000 \mu \mathrm{m}$ (regional metamorphic) $\mathrm{Mn}$ diffusion pattern in Barrovian garnets.

According to our model, episodic advective heating occurs on all time scales, with the effects of numerous events of short time scale contributing to produce a thermal episode on a larger time scale, and numerous events on this larger time scale contributing to produce a thermal episode over a time scale larger still. This heating scenario may be best described as self-similar. Within the main heating zone, self-similar heating would leave the mark of a continuum of thermal length scales, whose sum effect is the regional metamorphism, felt over a broader distance.

Implications for metamorphic heat sources. Self-similar heating in the highest grades of the Barrovian metamorphic series places restrictions on the nature of the heat sources that caused the metamorphism. Length-scale to time-scale relationships for conductive dissipation of metamorphic heat by thermal diffusion (equation (3)) dictate that transient heating episodes (tens of thousands of years in duration) must be associated with smallscale heat sources. A number of small-scale syn-metamorphic heat sources can be linked to the syn-metamorphic shear zones of Ashcroft et al. (1984), which occur in the NE of the Grampian terrane. Sheeted mafic magmas appear to have been emplaced into the shear zones during metamorphism (Fettes 1970; Viete et al. 2010a) and increased permeability (and fluid access) and mechanical work represent potential heat sources intrinsic to actively deforming regions. Incremental emplacement of magmas in association with hot fluid fluxing and/or shear heating during episodic movement on a large-scale, mid-crustal shear zone system offers a realistic option for the origin of pulses of metamorphic heat to produce the Barrovian metamorphic series. We suggest that situations where heating associated with orogenesis is brief and transient require tectonism accommodated by activity of major shear zones, which concentrate thin sources of metamorphic heat and whose episodic activity accommodates episodic thermal behaviour.

\section{The diffusivity of Mn in garnet}

Ague \& Baxter (2007), using the Arrhenius parameters recommended by Carlson (2006) to forward model major element diffusion in garnet, arrived at estimates of the order of 100$300 \mathrm{ka}$ for the duration of heating responsible for producing $c$. $100 \mu \mathrm{m}$ diffusion textures preserved in garnets from the sillimanite zone of the Barrovian metamorphic series. This study suggests that the features that Ague \& Baxter (2007) studied developed as the result of a late and localized thermal overprint on the regional metamorphic event and not the regional-scale thermal event itself. Using the Arrhenius parameters of Carlson (2006), the regional-scale thermal anomaly (and c. $1000 \mu \mathrm{m} \mathrm{Mn}$ diffusion) will have developed over 10-30 Ma and disagreements between the duration of metamorphic heating and the duration of Grampian orogenesis (c. 12-18 Ma: Dewey \& Mange 1999; Friedrich et al. 1999; Oliver et al. 2000; Dewey 2005) arise. The Arrhenius parameters of Chakraborty \& Ganguly (1992) predict less retentive diffusion behaviour at sillimanite-grade conditions ( $T=670{ }^{\circ} \mathrm{C}, P=6.1 \mathrm{kbar}$ ) compared with those of Carlson (2006) (Table 2). Observed Mn-in-almandine behaviour from the
Barrovian metamorphic series, Scotland, is consistent with Arrhenius parameters that produce $\mathrm{Mn}$-in-almandine diffusivity values (at amphibolite-facies conditions) between those predicted by the Chakraborty \& Ganguly (1992) dataset and those predicted by the Carlson (2006) dataset (Fig. 9). Notably, overlap occurs between the Mn-in-almandine Arrhenius parameters of Chakraborty \& Ganguly (1992) and those of Carlson (2006) when standard errors on the Arrhenius parameters are considered (see Table 2). The shaded region of the Arrhenius plot of Fig. 9 represents $\mathrm{Mn}$-in-almandine diffusivities at sillimanite-grade conditions $\left(\right.$ c. $\left.670{ }^{\circ} \mathrm{C}\right)$ between that recommended by Chakraborty \& Ganguly (1992) and that recommended by Carlson (2006). Length scales of $\mathrm{Mn}$ diffusion for garnet-zone samples that experienced peak metamorphic temperatures of $c .530{ }^{\circ} \mathrm{C}$ are less than $50 \mu \mathrm{m}$ (Fig. 4) and shorter than those for the sillimanite zone (c. $1000 \mu \mathrm{m}$ : Fig. 4) by at least a factor of 20. If time scales for Barrovian thermal activity were similar for the sillimanite zone and the garnet zone, Mn diffusivity for the garnet zone must have been shorter than that for the sillimanite zone by at least a factor of 400, as indicated in Figure 9.

\section{Conclusion}

Geochemical characterization of zoning patterns in garnets from the Barrovian metamorphic series was performed using electron microprobe and LA-ICP-MS techniques. The data show that, with increasing metamorphic grade across the Barrovian metamorphic series, Mn decreases in concentration in garnet cores and increases in concentration in garnet rims, for little change in the $\mathrm{Y}$ zoning. Because of issues relating to the effect of growth timing on initial Mn and Y zoning patterns, such observations provide no assurance of grain-scale diffusion during the Barrovian metamorphism.

Secondary compositional zoning in $\mathrm{Ca}$ and $\mathrm{Mn}$, superimposed on the grain-scale bell-shaped zoning, is apparent on c. $250 \mu \mathrm{m}$ length scales in some garnets from the garnet and staurolite zones of the Barrovian metamorphic series. Such secondary compositional zoning occurs on c. $1000 \mu \mathrm{m}$ length scales in Ca, but is absent in $\mathrm{Mn}$ in garnets from the sillimanite zone. This observation is consistent with diffusion of Mn during sillimanitegrade Barrovian metamorphism over length scales greater than $1000 \mu \mathrm{m}$, for little diffusion of $\mathrm{Ca}$. Concentration shadows on the scale of c. $300 \mu \mathrm{m}$ occur rim-side of large, Mn-free inclusions (or inclusion clusters) in high-grade garnets and provide further evidence for radial core-to-rim movement of $\mathrm{Mn}$ on the scale of $1000 \mu \mathrm{m}$ during the Barrovian metamorphism in Scotland. We suggest that variation in garnet composition patterns across the Barrovian metamorphic series (see Atherton 1968; Dempster 1985) resulted from millimetre-scale diffusion in the highestgrade tones during the Barrovian regional thermal event.

Sillimanite-grade garnets from the Barrovian metamorphic series carry evidence for additional Mn diffusion over smaller length scales $(c .100 \mu \mathrm{m})$ between sillimanite-grade rim domains and lower-grade cores. Diffusion features preserved within a single garnet over two length scales that vary by an order of magnitude will form as the result of thermal activity (at similar conditions) over time scales that vary by two orders of magnitude. Recent work has estimated the duration of thermal activity associated with the Barrrovian metamorphism at a few million years (see Dewey \& Mange 1999; Reverdatto \& Polyansky 2004; Viete et al. 2010b). It appears that thermal events associated with the Barrovian metamorphism at least display bimodality, with regional metamorphism over a few million years being attended by localized, short time-scale (tens of thousands of year) thermal 


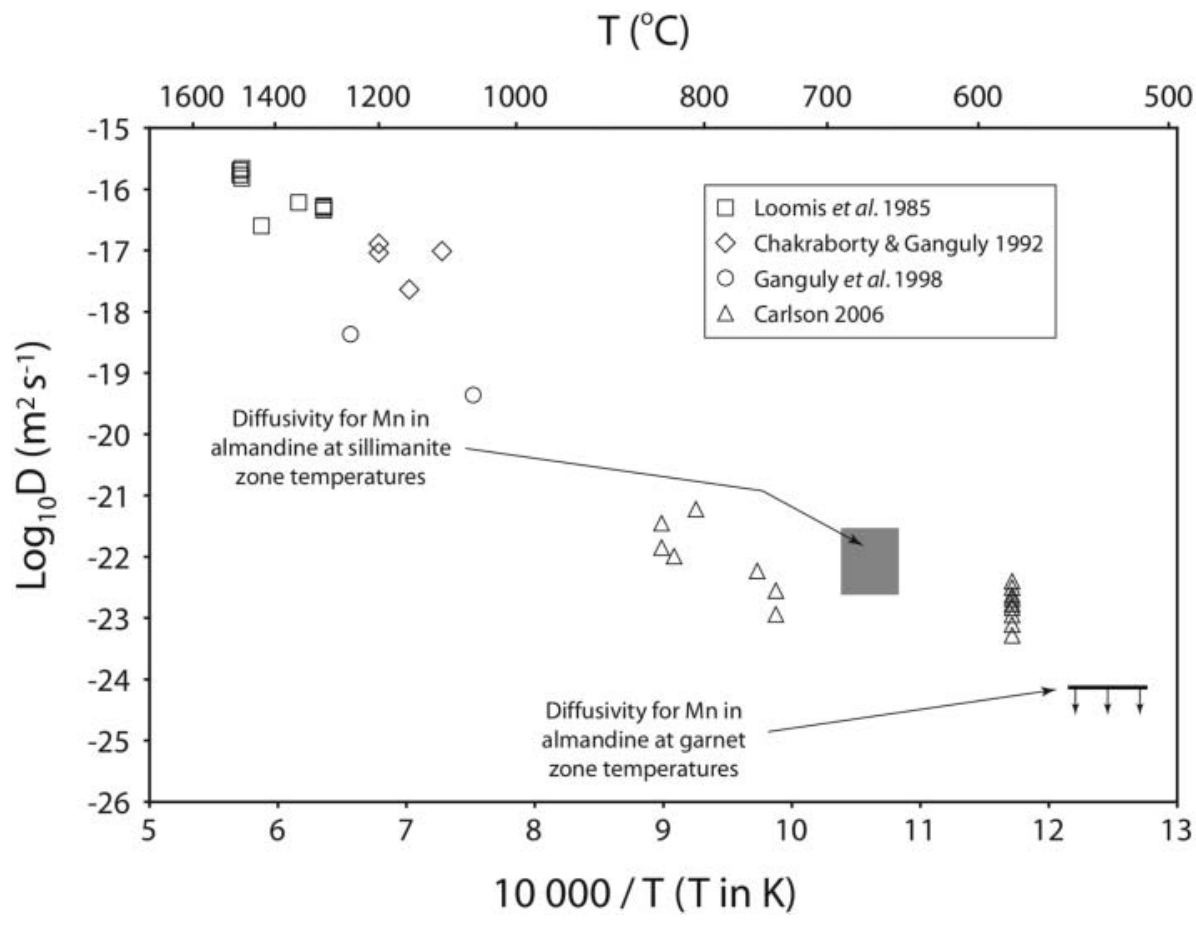

Fig. 9. Arrhenius plot showing laboratory results for Mn-in-almandine diffusivity and the range of diffusivity values that, on the basis of the results of this study, should be expected for typical temperatures of metamorphism in Barrovian-type settings. events. These data are consistent with a new self-similar heating model that holds heat accumulated within the highest-grade regions of the Barrovian metamorphic series, following numerous, short time-scale heating episodes, responsible for the Barrovian regional metamorphism over a few million years. Thus, the localized, sillimanite-grade metamorphic overprint on the Barrovian regional metamorphic pattern described by Chinner (1966) and Harte \& Hudson (1979) would record late, short time-scale heating events associated with the Barrovian regional metamorphism, whose effects were not assimilated by the regional metamorphic event.

We suggest that shear zones of the type that occur in association with the highest-grade Barrovian metamorphic units in the Grampian Terrane, Scotland (see Ashcroft et al. 1984) provide an ideal heat source for self-similar heating contributing to regional metamorphism over a few million years. Episodic movement within the shear zones and associated permeability increases could have allowed magma and hot fluids access to the shear zone and would have produced heat by mechanical work. If the heat pulses were closely enough spaced in time, the heat they introduced to the crust could have accumulated to form the regional thermal anomaly.

D. R. Viete acknowledges financial support provided by the Commonwealth Government of Australia in the form of an Australian Postgraduate Award. Analytical and fieldwork costs were covered by Australian Research Council Discovery grants DP0343646 'Tectonic Reconstruction of the Evolution of the Alpine-Himalayan Orogenic Chain' and DP0449975 'Revisiting the Alpine Paradigm: The Role of Inversion Cycles in the Evolution of the European Alps'. The authors would like to acknowledge the technical aid of A. Norris and C.M. Allen of the Research School of Earth Sciences (RSES), The Australian National University (ANU), in production of the electron microprobe composition maps and the LA-ICP-MS profiles, respectively. Thanks go to G.J.H. Oliver of the University of St. Andrews, S.W. Richards of the RSES, ANU, and A. Corvino of Melbourne University for assistance on the ground in Scotland. A detailed review by J.J. Ague helped strengthen the manuscript.

\section{References}

Ague, J.J. \& Baxter, E.F. 2007. Brief thermal pulses during mountain building recorded by $\mathrm{Sr}$ diffusion in apatite and multicomponent diffusion in garnet. Earth and Planetary Science Letters, 261, 500-516.

Anderson, D.E. \& Olimpio, J.C. 1977. Progressive homogenisation of metamorphic garnets, South Morar, Scotland: evidence for volume diffusion. Canadian Mineralogist, 15, 205-216.

Ashcroft, W.A., Kneller, B.C., Leslie, A.G. \& Munro, M. 1984. Major shear zones and autochthonous Dalradian in the north-east Scottish Caledonides. Nature, 310, 760-762.

Atherton, M.P. 1968. The variation in garnet, biotite and chlorite composition in medium grade pelitic rocks from the Dalradian, Scotland, with particular reference to zonation in garnet. Contributions to Mineralogy and Petrology, 18, 347-371.

Ayres, M. \& VANCE, D. 1997. A comparative study of diffusion profiles in Himalayan and Dalradian garnets: constraints on diffusion data and the relative duration of the metamorphic events. Contributions to Mineralogy and Petrology, 128, 66-80.

BAKER, A.J. 1985. Pressures and temperatures of metamorphism in the Eastern Dalradian of Scotland. Journal of the Geological Society, London, 142, 137148 .

BALdwin, S.L. \& Lister, G.S. 1998. Thermochronology of the South Cyclades Shear Zone, Ios, Greece: Effects of ductile shear in the argon partial retention zone. Journal of Geophysical Research: Solid Earth, 103, 7315-7336.

BARROW, G. 1893. On an intrusion of muscovite-biotite gneiss in the southeastern Highlands of Scotland and its accompanying metamorphism. Quarterly Journal of the Geological Society of London, 49, 330-358.

Barrow, G. 1912. On the geology of Lower Dee-side and the southern Highland Border. Geological Association of London Proceedings, 23, 274-290.

Baxter, E.F., Ague, J.J. \& DePaolo, D.J. 2002. Prograde temperature-time evolution in the Barrovian type-locality constrained by $\mathrm{Sm} / \mathrm{Nd}$ garnet ages from Glen Clova, Scotland. Journal of the Geological Society, London, 159, $71-82$.

Breeding, C.M., Ague, J.J., Grove, M. \& Rupke, A.L. 2004. Isotopic and chemical alteration of zircon by metamorphic fluids: $\mathrm{U}-\mathrm{Pb}$ age depth profiling of zircon crystals from Barrow's garnet zone, northeast Scotland. American Mineralogist, 89, 1067-1077.

Carlson, W.D. 2006. Rates of Fe, Mg, Mn and $\mathrm{Ca}$ diffusion in garnet. American Mineralogist, 91, 1-11.

Chakraborty, S. \& Ganguly, J. 1992. Cation diffusion in aluminosilicate garnets: experimental determination in spessartine-almandine diffusion couples, evaluation of effective binary diffusion coefficients, and applications. Contributions to Mineralogy and Petrology, 111, 74-86.

Cherniak, D.J. \& Ryerson, F. J. 1993. A study of Strontium diffusion in apatite using Rutherford backscattering spectroscopy and ion implantation. Geochimica et Cosmochimica Acta, 57, 4653-4662. 
Chernoff, C.B. \& Carlson, W.D. 1999. Trace element zoning as a record of chemical disequilibrium during garnet growth. Geology, 27, 555-558.

Chinner, G.A. 1966. The distribution of temperature and pressure during Dalradian metamorphism. Quarterly Journal of the Geological Society of London, 122, 159-181

Cygan, R.T. \& Lasaga, A.C. 1985. Self-diffusion of magnesium in garnet at $750^{\circ}$ to $900^{\circ} \mathrm{C}$. American Journal of Science, $\mathbf{2 8 5}, 328-350$

Dempster, T.J. 1985. Garnet zoning and metamorphism of the Barrovian type area, Scotland. Contributions to Mineralogy and Petrology, 89, 30-38.

Dewey, J.F. 2005. Orogeny can be very short. Proceedings of the National Academy of Sciences of th USA, 102, 15286-15293.

Dewey, J.F. \& Mange, M.A. 1999. Petrography of Ordovician and Silurian sediments in the western Irish Caledonides: tracers of short-lived Ordovician continent-arc collision orogeny and the evolution of the Laurentian Appalachian-Caledonian margin. In: MaC Niocalll, C. \& Ryan, P.D. (eds) Continental Tectonics. Geological Society, London, Special Publications, 164, $55-107$.

Dodson, M.H. 1973. Closure temperature in cooling geochronological and petrological systems. Contributions to Mineralogy and Petrology, 40, 259274.

EgGins, S.M., Kinsley, L.P.J. \& Shelley, J.M.G. 1998. Deposition and element fractionation processes during atmospheric pressure laser sampling for analysis by ICP-MS. Applied Surface Science, 127-129, 278-286.

Elles, G.L. \& Tilley, C.E. 1930. Metamorphism in relation to structure in the Scottish Highlands. Transactions of the Royal Society of Edinburgh, 56, 621646.

England, P.C. \& Thompson, A.B. 1984. Pressure-temperature-time-paths of regional metamorphism I. Heat transfer during the evolution of regions of thickened continental crust. Journal of Petrology, 25, 894-928.

FetTEs, D.J. 1970. The structural and metamorphic state of the Dalradian rocks and their bearing on the age of emplacement of the basic sheet. Scottish Journal of Geology, 6, 108-118.

Fettes, D.J., Graham, C.M., Harte, B. \& Plant, J.A. 1986. Lineaments and basement domains: an alternative view of Dalradian evolution. Journal of the Geological Society, London, 143, 453-464.

Freer, R. 1979. An experimental measurement of cation diffusion in almandine garnet. Nature, 280, 220-222.

Freer, R. \& Edwards, A. 1999. An experimental study of $\mathrm{Ca}-(\mathrm{Fe}-\mathrm{Mg})$ interdiffusion in silicate garnets. Contributions to Mineralogy and Petrology, 134, 370-379

Friedrich, A.M., Bowring, S.A., Martin, M.W. \& Hodges, K.V. 1999. Shortlived continental magmatic arc at Connemara, western Irish Caledonides: implications for the age of the Grampian Orogeny. Geology, 27, 27-30.

Ganguly, J., Cheng, W. \& Ganguly, J. 1998. Cation diffusion in aluminosilicate garnets: experimental determination in pyrope-almandine diffusion couples. Contributions to Mineralogy and Petrology, 131, 171-180.

Harte, B. 1987. Glen Esk Dalradian, Barrovian metamorphic zones. In: TrewiN, N.H., Kneller, B.C. \& Gillen, C. (eds) Excursion Guide to the Geology of the Aberdeen Area. Geological Society of Aberdeen, Aberdeen, 193-210.

Harte, B. \& Hudson, N.F.C. 1979. Pelite facies series and the temperatures and pressures of Dalradian metamorphism in E Scotland. In: HARris, A.L., Holland, C.H. \& Leake, B.E. (eds) The Caledonides of the British Isles Reviewed. Geological Society, London, Special Publications, 8, 323-337.

Hollister, L.S. 1966. Garnet zoning: an interpretation based on the Rayleigh fractionation model. Science, 154, 1647-1651.

Hudson, N.F.C. 1980. Regional metamorphism of some Dalradian pelites in the Buchan area, NE Scotland. Contributions to Mineralogy and Petrology, 73, 39-51.

JAFFE, H.W. 1951. The role of yttrium and other minor elements in the garnet group. American Mineralogist, 36, 133-155.

Keay, S., Lister, G.S. \& Buick, I.S. 2001. The timing of partial melting, Barrovian metamorphism and granite intrusion in the Naxos metamorphic core complex, Cyclades, Aegean Sea, Greece. Tectonophysics, 342, 275-312.

KoHN, M.J. 2004. Oscillatory- and sector-zoned garnets record cyclic (?) rapid thrusting in central Nepal. Geochemistry, Geophysics, Geosystems, 5, Q12014.

Kohn, M.J. \& Spear, F. 2000. Retrograde net transfer reaction insurance for pressure-temperature estimates. Geology, 28, 1127-1130.

KRETZ, R. 1983. Symbols for rock-forming minerals. American Mineralogist, 68 ,
$277-279$

Lambert, R.S.J. \& McKerrow, W.S. 1976. The Grampian Orogeny. Scottish Journal of Geology, 12, 271-292.

LANZIRotTI, A. 1995. Yttrium zoning in metamorphic garnets. Geochimica et Cosmochimica Acta, 59, 4105-4110.

LAsaga, A.C. 1983. Geospeedometry: an extension of geothermometry. In SaXena, S.K. (ed.) Kinetics and Equilibrium in Mineral Reactions. Springer, New York, 81-114.

Lister, G.S. \& Baldwin, S.L. 1993. Plutonism and the origin of metamorphic core complexes. Geology, 21, 607-610.

Loomis, T.P., Ganguly, J. \& ElPhick, S.C. 1985. Experimental determination of cation diffusivities in aluminosilicate garnets. II. Multicomponent simulations and tracer diffusion coefficients. Contributions to Mineralogy and Petrology, 90, $45-51$.

MCLellan, E. 1985. Metamorphic reactions in the kyanite and sillimanite zones of the Barrovian type area. Journal of Petrology, 26, 789-818.

Oliver, G.J.H., Chen, F., Buchwaldt, R. \& Hegner, E. 2000. Fast tectonometamorphism and exhumation in the type area of the Barrovian and Buchan zones. Geology, 28, 459-462.

Pearce, N.J.G., Perkins, W.T., Westgate, J.A., Gorton, M.P., Jackson, S.E., NeAL, S.E. \& Chenery, S.P. 1997. A compilation of new and published major and trace element data for NIST SRM 610 and NIST SRM 612 glass reference materials. Geostandards and Geoanalytical Research, 21, 115-144.

Pownceby, M.I., Wall, V.J. \& O’Neill, H.St.C. 1987. Fe-Mn partitioning between garnet and ilmenite: experimental calibration and applications. Contributions to Mineralogy and Petrology, 97, 116-126.

Pyle, J.M. \& Spear, F.S. 1999. Yttrium zoning in garnet: Coupling of major and accessory phases during metamorphic reactions. Geological Materials Research, 1, 1-49.

Reverdatto, V.V. \& Polyansky, O.P. 2004. Modelling of the thermal history of metamorphic zoning in the Connemara region (western Ireland). Tectonophysics, 379, 77-91.

Schwandt, C.S., Cygan, R.T. \& Westrich, H.R. 1995. Mg self-diffusion in pyrope garnet. American Mineralogist, 80, 483-490.

Schwandt, C.S., Cygan, R.T. \& Westrich, H.R. 1996. Ca self-diffusion in grossular garnet. American Mineralogist, 81, 448-451.

Skora, S., Baumgartner, L.P., Mahlen, N.J., Johnson, C.M., Pilet, S. \& Hellebrand, E. 2006. Diffusion-limited REE uptake by eclogite garnets and its consequences for Lu-Hf and Sm-Nd geochronology. Contributions to Mineralogy and Petrology, 152, 703-720.

Soper, N.J., Ryan, P.D. \& Dewey, J.F. 1999. Age of the Grampian Orogeny in Scotland and Ireland. Journal of the Geological Society, London, 156, 12311236

Thompson, A.B. 1976. Mineral reactions in pelitic rocks. II. Calculation of some $P-T-X(\mathrm{Fe}-\mathrm{Mg})$ phase relations. American Journal of Science, 276, $425-$ 454.

Vielzeuf, D., Barronet, A., Perchuk, A.L., Laporte, D. \& Baker, M.B. 2007. Calcium diffusivity in alumino-silicate garnets: an experimental and ATEM study. Contributions to Mineralogy and Petrology, 154, 153-170.

VIETE, D.R. 2009. The nature and origin of regional metamorphism: observations from the Barrovian metamorphic series of Scotland. $\mathrm{PhD}$ thesis, The Australian National University.

Viete, D.R., Richards, S.W., Lister, G.S., Oliver, G.J.H. \& BanKs, G.J. $2010 a$ Lithospheric-scale extension during Grampian orogenesis in Scotland. In Law, R.D., Butler, R.W.H., Holdsworth. R.E., Krabbendam, M. \& Strachan, R.A. (eds) Continental Tectonics and Mountain Building-The Legacy of Peach and Horne Geological Society, London, Special Publications, 335, 121-160

Viete, D.R., Forster, M.A. \& Lister, G.S. 2010b. The nature and origin of the Barrovian metamorphism, Scotland: ${ }^{40} \mathrm{Ar} /{ }^{39} \mathrm{Ar}$ age patterns and the duration of metamorphism in the biotite zone. Journal of the Geological Society, London, 168, 133-146.

Wijbrans, J.R. \& McDougall, I. 1988. Metamorphic evolution of the Attic Cycladic Metamorphic Belt on Naxos (Cyclades, Greece) utilizing ${ }^{40} \mathrm{Ar} /{ }^{39} \mathrm{Ar}$ age spectrum measurements. Journal of Metamorphic Geology, 6, 571-594.

Woodsworth, G.J. 1977. Homogenization of zoned garnets from pelitic schists. Canadian Mineralogist, 15, 230-242.

YARDLEY, B.W.D. 1977. An empirical study of diffusion in garnet. American Mineralogist, 62, 793-800. 